\title{
On the Peculiarities of Plaice from Different Fishing Grounds.
}

\author{
By
}

\author{
J. T. Cunningham, M.A.
}

THE investigation here described may be regarded as the natural sequel of the observations by which I showed that the plaice of the Brown Ridges, as well as those from the Plymouth grounds, were smaller when they attained to sexual maturity than those of the northern part of the North Sea. Mr. Holt, in 1894, published in this Journal some observations on the dwarfed and ciliated or spinulated plaice of the Baltic; and Dr. Heincke, now Director of the German Biological Station at Heligoland, had suggested as a probability that the plaice of the Heligoland region were a smaller geographical race, distinguishable by special characters from those of other regions. I referred to this subject at the end of my paper on the Physical and Biological Conditions in the North Sea, in the preceding number of this Journal, and mentioned the paper in which Georg Duncker* has recorded and discussed the results of an examination of samples of plaice and flounder from various localities. Among these localities was the Heligoland region; but Duncker had not compared the plaice of Heligoland with those of other parts of the North Sea. I have not had time to make as extensive an investigation of the matter as would be desirable. I commenced my observations at Lowestoft in September last, and continued them until the beginning of December, when I quitted the service of the Marine Biological Association. I have examined samples of plaice from the Brown Ridges, from the grounds off the Norfolk coast, from a position north-east of the Dogger Bank, and from the neighbourhood of the Eddystone Lighthouse. I have also endeavoured to acquaint myself with the complete geographical distribution of the plaice and the species most nearly allied to it, and for this purpose devoted several days to the examination of specimens in the National Collection. I have to thank Mr. G. A. Boulenger, F.R.S.,

*Wiss Meeresuntersuch., Neue Folge, Bd. I., Heft. 2, 1896. 
fer his kindness and courtesy in providing me with facilities for carrying out this part of the work in the Natural History Museum at South Kensington. I will describe first the characters of the samples of plaice from the North Sea and the South-west coast.

\section{The Variations Observed in Plaice from different parts of the North Sea and Channel.}

The method I have employed is not exactly the same as that adopted by Duncker, who followed the example set by Heincke in his papers on the varieties of herrings, in the publications of the Commission zur Untersuchung der Deutschen Meere. The first step in either method is the actual observation by measurement and counting of the principal characters in each individual fish. The characters selected by Duncker were the following :-

1. The number of vertebræ in the caudal peduncle.

2. The number of vertebræ between the abdomen and the caudal peduncle.

3. The number of abdominal vertebræ.

4. The total number of vertebræ.

5. The number of gill-rakers on the first branchial arch.

6 . The number of dorsal fin-rays.

7. The number of ventral fin-rays.

8. The length of the caudal peduncle.

9. The mean height of the same.

10. The greatest height of the body without the marginal, or dorsal and ventral, fins.

11. The greatest length of the head, on the upper side.

12. The extent of spinulation in the males.

In accordance with Heincke's method Duncker divided the variations observed in each of these characters into stages, which he denoted by symbols. The object of this is, firstly, to eliminate small errors of observation; secondly, to allow the differences to become more distinct; and thirdly, to show the relations between different variations; that is, to exhibit what is known as correlation. The character of each fish is thus represented by a formula consisting of a number of symbols, and a difference between local races may be demonstrated by the fact that the most frequent formulæ are different in the two cases.

I decided to neglect the examination of the number of vertebræ altogether. The variations in these were too small to be likely to exhibit any differences between the different samples I was investigating, and so far as they existed would be sufficiently represented by the variations in the number of fin-rays and length of the caudal peduncle. 
The exposure and enumeration of the vertebræ are operations that take some time, and by omitting them I was able to examine a larger number of specimens. I omitted also the mean height of the caudal peduncle, the determination of which did not appear to be susceptible of great accuracy, and I did not follow Duncker in combining together head-length and height of body. I added the examination of another character, namely, the number of the tubercles, whose prominence or flatness I also noted.

The characters I have examined are therefore the following :-

1. Maximum height of body without fins.

2. The length of the head, from the apex of the lower jaw to the end of the opercular bone, on the upper side.

3. The length of the caudal peduncle, from a line joining the ends of the marginal fins to the middle of the line of articulation of the caudal fin-rays.

4. The length of the caudal fin, from the latter point to the end of the middle rays.

5. The number of the tubercles on the head behind the eyes. side.

6. The number of the gill-rakers on the first branchial arch, upper

7. The number of the dorsal rays.

8. The number of the ventral rays.

9. The number of ciliated rays in the dorsal and ventral fins.

10. The ciliated (spinulated) scales on the head and body.

11. The maturity or immaturity of each specimen.

The measurements of lengths were made with a millimetre scale and a pair of dividers, and they were only taken to the nearest millimetre. It did not appear that greater accuracy was possible. The body of a plaice is not rigid like that of a crustacean, but any part of it may be stretched or compressed a fraction of a millimetre, so that any greater accuracy of measurement would have been apparent and not real. No such qualification applies to the enumerations of numerical characters, which are absolute, and were made with the greatest care. The lengths of parts after measurement were calculated as hundredths of the total body-length, which was measured from the apex of the lower jaw to the end of the tail. To obtain this length the fish was laid upon the measuring-rod, and the lower jaw was pushed into contact with the vertical surface of a piece of wood placed upright at one of the lines of the measure, the length at the end of the tail being then read off directly. The measure was always taken with the lower jaw just closed and not pressed. As the lengths were only taken to millimetres it seemed useless to calculate the proportions to higher fractions than hundredths of the body-length. The fish varied from about 200 to 
$500 \mathrm{~mm}$. in length, so that 01 of the total length varied from $2 \mathrm{~mm}$. to $5 \mathrm{~mm}$., but $\cdot 001$ would have implied accuracy to from $\cdot 2$ to $5 \mathrm{~mm}$., which was greater than the accuracy of direct measurement. Considering the great variations in the proportions with age and condition of the individual, differences between local races not exhibited in hundredths of the total length may be regarded as quite unimportant.

The direct results of the examination of the specimens and calculation of percentages are recorded in Tables $\mathrm{A}$ appended to this paper. The sexes are recorded separately, and the specimens given in order of total length, in order to show what variations depend upon sex or increase in size.

The comparison between the samples from different localities, in Tables $B$, has been made by placing side by side the actual numbers of individuals observed to have each degree of variation which was distinguished. Duncker has given tables of frequency, but they differ from mine in two respects; firstly, that he takes the larger stages of variation mentioned above, and secondly, that he has given the percentage of individuals, not the actual number. As the number of individuals was in my investigation rather small, and as the object was only to ascertain and compare the distribution of the variations, no advantage appeared to be gained by comparing the percentages of individuals instead of the actual numbers.

The largest number of individuals have been examined in the case of the Brown Ridges and the Norfolk coast, these being the two principal distinct regions where the sailing trawlers of Lowestoft work. From the other two regions, namely, the Eddystone grounds and the ground to the north-east of the Dogger Bank, a smaller number were obtained. All those from the Brown Ridges were examined at Lowestoft, and also the greater number of those frorn off the Norfolk coast: the latter include samples taken outside the Dowsing Bank, off Cromer, and off the Well Bank. An additional sample, taken fourteen miles from Cromer, was sent to me in London from Lowestoft. The Plymouth samples were sent from the Plymouth Laboratory. The remaining sample was a box sent from Billingsgate, and stated by the sender to have been caught 220 miles from Smith's Knoll, just to the north of the tail of the Dogger Bank, at a depth of 25 fathoms.

I will proceed now to the comparison of the various characters in the samples.

According to the statistical enquiries of Mr. Francis Galton and Professor Weldon the magnitude of a character which occurs with the greatest frequency nearly coincides with the arithmetical mean of all the observed magnitudes, and the frequencies of the other magnitudes are symmetrically disposed about the maximum frequency. 
In my results in the majority of cases an approximation to this condition is visible; but I have not calculated the actual mean, or attempted to determine the probable error or mean error of the deviations. The question I have proposed to investigate is merely whether there are between the samples differences in the characters examined, which are sufficient to be definitely demonstrated by comparing the frequencies with which the variations occur.

The most frequent height of body in the plaice of Brown Ridges is 39 , both in the males and females. In the females from the Norfolk coast it is the same, while in the males it is 38 . But we cannot say therefore that the Norfolk males are narrower, for among the Brown Ridges specimens there are 16 having a body-height less than 38 per cent., and among the Norfolk coast males only 10 . On the contrary, the number of specimens having heights of 40,41 , and 42 , is greater in the Norfolk coast males than in those of the Brown Ridges, and this does not appear to be due to a difference of age or stage of growth. Duncker found that a considerable decrease in breadth took place between $15 \mathrm{~cm}$. and $20 \mathrm{~cm}$. in length, and an increase after $30 \mathrm{~cm}$. But where two local races are known to differ in absolute size, like those we are now comparing, the question is whether we are comparing samples of corresponding stages and ages. Now there are rather more specimens between $20 \mathrm{~cm}$. and $25 \mathrm{~cm}$. in the Norfolk coast sample than in the other, and therefore more young specimens, and these should be rather narrower than the old specimens; but we have no reason to suppose that the largest specimens in the Norfolk coast sample are older than those from the Brown Ridges. On the whole, then, we must conclude that the male plaice from the Norfolk coast are broader than those from the Brown Ridges. The single male at 45 was only $20 \cdot 7 \mathrm{~cm}$. long. The females of the Norfolk coast are also slightly broader than those from the Brown Ridges.

It will be seen that the difference between the sexes in height of body is very slight, but what superiority there is, is on the side of the females, and this is in agreement with Duncker's results.

In the Plymouth females the body-height 38 per cent. is the most frequent, while the males appear to be broader, the maximum being at 39 . On the other hand, in the plaice from north of the Dogger Bank, although there is no maximum frequency, the number of individuals being small, the much greater breadth of body is sufficiently obvious. A comparison of the lists of specimens from the Norfolk coast, and from the more northern ground which I have given, will show that the greater breadth of the more 
northern specimens does not depend entirely on age or size. A similar great height of body was found by Duncker in the Cattegat plaice, which exceed in this respect the plaice of the Baltic. The latter are stated to be mostly from 38 to 39 per cent. in height, like my specimens from Brown Ridges and the Norfolk coast. Now the largest specimens from the Cattegat examined by Duncker were between 39 and $40 \mathrm{~cm}$. in total length; but Petersen, in the Report of the Danish Biological Station, 1893, records specimens up to nearly 22 inches, or $55 \mathrm{~cm}$. Thus the Cattegat plaice do not appear to be very much smaller on the whole than those of the northern part of the North Sea, and we may conclude that they are similar to these. Whether they agree with them in other characters will be seen in the course of this paper.

In the last two columns I have added the figures of Plymouth and Brown Ridges to represent a southern race, and the figures of the other two localities to represent a northern, and it will be seen that though the maximum frequency still remains in both sexes of both races at 39 , yet the northern race is distinctly broader.

In the second set of tables are seen the frequencies obtained by taking all individuals regardless of sex, and here also the greater breadth of the Norfolk coast specimens, and of those from north-east of the Dogger Bank, is evident.

Length of Head. The most conspicuous fact that appears from the figures referring to this character is that in all four cases the females are distinctly longer in the head than the males. This agrees with Duncker's results. Duncker also found that the length of the head decreased during the growth of the fish. Such decrease is evident in my list of the males from the Brown Ridges, where the length 20 occurs seven times among the 15 largest specimens, and only greater lengths occur among the 37 smaller. The length 19 per cent. occurs only once, and that is in the largest male from beyond the Dogger Bank. But a similar decrease is not perceptible in the females. In the Norfolk coast females the length 24 per cent. occurs eight times, twice in the largest specimens, three times in specimens between 30 and $40 \mathrm{~cm}$., and three times in specimens between $20 \mathrm{~cm}$. and $30 \mathrm{~cm}$. The greater length of head, then, in the females of the Norfolk coast is not due to a greater proportion of young specimens in this sample.

In the samples from the Brown Ridges and the Norfolk coast the maximum frequency is in both sexes at 22 , but in the case of the Norfolk coast the greater lengths are more frequent, and the shorter less frequent than in the case of the Brown Ridges. It is not, however, so obvious that the specimens from north-east of the Dogger Bank have longer heads than those of the Norfolk coast, or even than those 
of the Brown Ridges. If we take into consideration the small number of specimens we see that there is a slight superiority over the latter. The Plymouth specimens again, as far as we can judge from so small a sample, appear to be a little shorter in the head than those of the Brown Ridges; in the males of these only the most frequent headlength is 21 , while in all the other cases the maximum is at 22 . In treating the samples in two sections only, southern and northern, we see that the former are shorter in the head. When the numbers of the two sexes are combined, the Norfolk coast sample appears to have the longest head on account of the large number of females in this sample. The greater length of head in the northern plaice is evident when all the figures are combined into two columns.

Caudal Peduncle. In this character a constant difference between the sexes is not evident, but again a slight superiority in the northern samples is indicated.

Length of Caudal Fin. The caudal fin appears to be distinctly longer in the sample from the Norfolk coast than in that from the Brown Ridges, the most frequent length being 19 per cent. in the former, 18 per cent. in the latter. The Plymouth specimens, however, have rather longer tails, at least in the males, than those of the Brown Ridges, and those of the north-east of the Dogger Bank rather shorter than those of the Norfolk coast. I am inclined to think that a reduction in the relative length of the caudal fin takes place as the limit of increase in size is reached; in other words, that the fin is shortest in the oldest specimens, the caudal fin growing less than the body in adult specimens, especially when the size reached is great. Thus two of the three specimens of the Norfolk coast, in which the caudal fin is only 16 per cent. of the total length, are the two largest, $56.8 \mathrm{~cm}$. and $63.0 \mathrm{~cm}$. respectively. The Norfolk coast samples certainly include more young specimens than any of the others, as well as absolutely the smallest specimens examined, as is natural from the fact that the district is nearest to the shore; and in this sample the greater lengths of caudal fin are most frequent.

Number of Tubercles. This is a character which is not considered by Duncker. Numerical characters are not usually subject to change with growth in the individual, but this character may possibly change to some extent. When one or more tubercles are so flat as to be virtually obsolete, I have counted only those which were distinct, while in other cases some of the five usually present are represented by two or more separate points. The flatness or prominence of the tubercles must be considered, and it is not fully represented in the tables.

In all cases the normal number 5 is most frequent. A reduction occurs most commonly in the sample from the Norfolk coast; it does 
not occur in the specimens from the Brown Ridges, but is more common in the Plymouth specimens than in those from north-east of the Dogger Bank.

The description "flat," however, in reference to the tubercles, occurs frequently among the notes of examination of the specimens from beyond the Dogger Bank, and least frequently in connection with the Brown Ridges specimens. The reduction of the tubercles, which makes some of them virtually obsolete and the rest less prominent, was particularly noticed in the largest females from the Norfolk coast, especially in a sample sent me in November, and caught fourteen miles off Cromer. In many of these I thought the condition suggested that the tubercles had actually been subject to mechanical friction. In the same specimens the edges of the marginal fins were thickened and contracted, evidently in consequence of frequent abrasion and healing. We know that the ground off the Norfolk coast is very rough and stony, and that the plaice is in the habit of burying itself in the ground it lives on. The fish also must doubtless push its head under stones and into the ground to obtain its prey; so that I think it very probable that the tubercles, as well as the edges of the fins, are worn away in the plaice of this district. The ground on the Brown Ridges, on the other hand, is composed of exceedingly fine smooth sand; that beyond the Dogger Bank is rather smooth; and on the Plymouth grounds both rough and smooth occur.

Gill-rakers. In all cases the most frequent number of the anterior processes on the first branchial arch is 10 , and there is not much difference in this character between the sexes or the samples from different localities. But there is seen in the females of the Norfolk coast a slight indication of an increase in the number; the numbers above 10 occur more frequently in proportion. Considering the large number of female specimens from the locality which were examined (91), this result is, I think, significant, and it is confirmed by a similar indication in the females of the most northern locality. We may infer that the number of gill-rakers increases as we proceed towards the north.

Fin-rays. The variation in the number of fin-rays is considerable, and the frequencies of the different variations are not very symmetrically distributed. The largest sample is that of the females of the Norfolk coast, and here the most frequent number in the dorsal fin is 72 ; but the middle frequency, which is almost as great, is 73 . The most frequent number in the males is 74 ; but, nevertheless, it will be seen that on the whole the number of fin-rays is greater in the females than in the males in all the samples; that is to say, in the former the higher numbers occur more frequently, and the lower 
numbers less frequently. In the females from the Brown Ridges there are two maxima for the dorsal rays: one at 70 , the other at 76 . Whether this indicates a true dimorphism, like that found by Professor Weldon in the-shore crabs of Naples with regard to their frontal breadth, I am not prepared to say, the number of individuals being too small. But it is clear that the females of the Brown Ridges have on the whole a slightly greater number of fin-rays than those of the Norfolk coast, and the same is true of the males. As in other cases, the Plymouth specimens seem to resemble those of the Brown Ridges; those from beyond the Dogger Bank to resemble those of the Norfolk coast, in this character. The most frequent number of anal rays in the Norfolk coast and Brown Ridges samples is 55, except in the males of the former, where it is 53 or 54 . As in the case of the dorsal rays, the figures show a slight superiority in number of anal rays of the southern samples over the northern, although the difference is not in either case very important.

Spinulation of the Scales, or Ciliation. In the tables of frequencies I have employed almost the same degrees of spinulation as Duncker, but have distinguished two degrees in the spinulation of the head instead of one. The degrees are (1) on the middle rays of the dorsal and ventral fins only; (2) also on the head in front of the preopercular bone; (3) also on the operculum; (4) also on the skin of the body near the edges, in the region over the interspinous bones; (5) spinulation extended over other areas of the body. In examining the specimens I counted and recorded the number of dorsal and anal fin-rays on which spinulated scales occurred, and in the first set of tables in which the characters of each specimen are given I have added the numbers together, and given for each specimen the total number of spinulated rays. One object of this was to ascertain whether the spinulation of the scales extended on to additional rays in proportion to the degree in which it extended to other parts of the body. The result is to show that there is no exact proportion between the number of finrays which are spinulated and the extension of the character on other parts of the body. The fact is that scales are also present along the middle rays of the dorsal and anal fins in the females and in the young males, although, like the scales on the other parts of the body, in these cases they are not furnished with spines on their outer edges. In a female $30.7 \mathrm{~cm}$. long from Plymouth I found that there were rudimentary scales on 24 of the dorsal rays and 21 of the ventral. The spinulation develops at about the time when the male becomes mature, and evidently develops very quickly, although it possibly increases with age. I obtained some male specimens of the Norfolk coast plaice from $20 \mathrm{~cm}$. to $25 \mathrm{~cm}$. in length on purpose to 
study the development of the spinulation on the scales. In a specimen $20.7 \mathrm{~cm}$. long, and another of $23.8 \mathrm{~cm}$., there was no trace of spines on the scales of the fin-rays, while in another $25.8 \mathrm{~cm}$. long they were just developing. In most cases there are not more than two spines on each scale, and on many scales only one spine. The spine commences as a deposit of calcareous matter in the shape of a short cone, and is formed not as an outgrowth from the scale, but as a separate deposit, of which the base afterwards becomes united to the scale. The position and shape of the growing spine are shown in Fig. 1.

In the table of the frequencies of the degrees of spinulation I have omitted those specimens from the males of Norfolk coast and the Brown Ridges which were below $26 \mathrm{~cm}$. in length. In the former case there were eight of these, leaving 41 to be considered; in the latter there were only two omitted, leaving 50. It will be seen that in both cases the second degree of spinulation is the most frequent, but it is equally evident

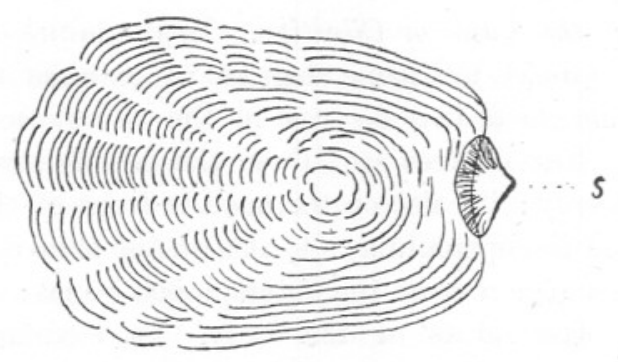

FIG. 1.

Scale of dorsal fin-ray of a plaice from the Norfolk coast, $25.8 \mathrm{~cm}$. long, magnified. $S$ the incipient spine at the outer edge of the scale.

that the higher degrees are somewhat more frequent in the specimens from the Norfolk coast. Now among the latter the smaller specimens must be younger and more immature than those of the same size from the Brown Ridges, and therefore the lower degrees of spinulation ought to be more frequent in the specimens from the Norfolk coast, if we consider only those which do not exceed the maximum length of those from the Brown Ridges. One specimen, however, of the three from the Norfolk coast which had no spinulation was actually mature-it was $36.5 \mathrm{~cm}$. long; the other two were apparently immature, and were smaller. This shows that the development of spinulation does not always correspond exactly to the attainment of maturity, although it does so usually. In the Norfolk coast sample there are 12 specimens exceeding in size the largest of the Brown Ridges plaice; the largest of these 12 is $48.9 \mathrm{~cm}$. long, the next largest is $43.2 \mathrm{~cm}$. Putting aside the largest, we cannot consider the other 11 to be older than any of the 
specimens from the Brown Ridges, because the difference is not greater than that which I have shown to exist in the length of the smallest mature in the two cases. The largest specimen from the Norfolk coast has the fourth degree of spinulation. Taking all these facts into consideration, I conclude that on the whole the spinulation is slightly but distinctly greater in the plaice from the Norfolk coast than in those from the Brown Ridges.

In the females also there is a slightly more frequent spinulation among the specimens from the Norfolk coast than in those from the Brown Ridges. It is rare to find any trace of the condition in the females, but it is by no means exclusively confined to the oldest or largest specimens. One of the three spinulated females from the Norfolk coast was only $27 \cdot 0 \mathrm{~cm}$. long, and apparently immature.

The much greater development of spinulation in the plaice from beyond the Dogger Bank is very evident from the figures. But we must consider how far this may be due to the greater age of the specimens, since the locality where they were captured is in greater depth of water and much farther from the coast than the district off the Norfolk coast, or even the Brown Ridges. Now in the males of the deep-water sample there are eight specimens over $40 \mathrm{~cm}$. in length, the largest being $47 \cdot 3 \mathrm{~cm}$. long; of these, in the smallest specimen, the degree of spinulation is 2 , in the largest 5 , and in the other six 4. Of the males from the Norfolk coast, six are over $40 \mathrm{~cm}$. in length, and the largest is $48.9 \mathrm{~cm}$. long; of these three have degree 2 , one degree 3 , and two only have degree 4 . We have no reason to suppose that the northern specimens are older, although not larger; the presumption is the contrary. Therefore we have sufficient proof that the plaice from the more northern locality are considerably more spinulated at the same age than the Norfolk coast specimens, and a fortiori than those of the Brown Ridges. There is evidence that the development of spinulation increases with age; but enough evidence has been here produced to show that the difference between my samples from different localities is not due to differences of age.

It may be pointed out as worthy of note that in the two females in which spinulation occurs among the specimens from beyond the Dogger Bank, it is present on the cheek, and almost entirely absent from the fins.

The males from Plymouth appear to be rather more spinulated than those from the Brown Ridges; but it may be mentioned that in the specimen which is recorded as having degree 4, the spinulation of the interspinous regions was only just perceptible.

Recapitulation. The investigation shows that although the number of individuals examined is not so large as it should be, yet there are 
distinct differences in structural characters between the samples, especially between those of the Norfolk coast and the Brown Ridges, which would almost certainly be confirmed by examination of a larger number of specimens.

Omitting the tubercles and the length of the caudal peduncic, in which the indications are not very distinct, I find distinct differences in the following characters: Height of body, length of head, length of caudal fin, spinulation of scales, number of gill-rakers, number of finrays. The length of the caudal fin decreases apparently with age, and it is not very evident that it is a permanent characteristic of the different local forms. We have then left three characters of proportion and two of number. The first three characters all vary with age, the latter two do not change in the individual.

The change in the height of the body with age does not appear to be very constant or important in my samples; the height is distinctly greater in the northern samples than in the southern. The difference between the sexes is slight.

The length of head is a marked sexual character, being greater in the females; it decreases as age advances, but within the limits of size of my specimens the decrease is not obvious in the females, and not very important in the males. The length of head is a little greater in the northern samples.

The spinulation of the scales is a character, with few exceptions, confined to mature males, and forms the most conspicuous local peculiarity. There is no important difference in this character between the plaice of Plymouth and those of the Brown Ridges; but on the Norfolk coast, and still more beyond the Dogger Bank, it is much more developed than on the Brown Ridges.

The number of fin-rays is slightly greater in the females, and is somewhat less in the northern samples than in the southern.

The gill-rakers, on the contrary, are slightly increased in the northern samples as compared with the southern.

\section{Comparison of the Local Forms Examined with those OF OTHER REgIONS.}

Duncker examined 35 males and 45 females caught in the neighbourhood of Heligoland. The males were from $13.4 \mathrm{~cm}$. to $28.9 \mathrm{~cm}$. in length, the females from $19.3 \mathrm{~cm}$. to $32.6 \mathrm{~cm}$. Now I have shown in a previous paper that no plaice from this district were mature below 11 in., or very nearly $28 \mathrm{~cm}$., in two samples which I examined, containing together 307 specimens. It is not surprising, therefore, that in Duncker's specimens the degree of spinulation was much lower than 
in the samples described above from the Norfolk coast, and even from the Brown Ridges. Duncker's male specimens from Heligoland must have been all, or nearly all, immature. It will be seen from my list of Norfolk coast specimens that spinulation often commences on the fin-rays before maturity, and this accounts for the fact that the first stage of the character occurs in a considerable proportion of Duncker's specimens. The smallest in which it occurs is $20.6 \mathrm{~cm}$. long; the largest in which there is no spinulation at all is $26.6 \mathrm{~cm}$. long. In my Norfolk coast samples the smallest specimen in which spinulation occurs is $23.5 \mathrm{~cm}$. long, and only one smaller than this was examined, while the largest in which it was absent is $36.5 \mathrm{~cm}$. long. Degree 2 occurs in Duncker's specimens, in one specimen $24.5 \mathrm{~cm}$. long, and one $26.7 \mathrm{~cm}$. long, while in the Norfolk coast specimens the smallest in which this degree occurs is $27.3 \mathrm{~cm}$. long. It is not possible then to conclude from Duncker's specimens whether in the race to which they belong spinulation is much developed or little. There is nothing to contradict the probability that they belong to a race as strongly spinulated in the adult males as the Norfolk coast form or that from beyond the Dogger, and we certainly have no evidence at present that they are less spinulated than those of the Brown Ridges. Duncker unfortunately overlooked the question of the age and maturity of his samples.

Duncker divides the height of the body into only two degrees, and combines it in his formulæ with the length of the head, and I can therefore only attempt to make a comparison from his descriptive remarks. He says that the height exceeds 38 per cent. in the Heligoland plaice but seldom, and it would seem from this that these plaice are rather narrower than those from the Norfolk coast of the same size, and perhaps than those of the Brown Ridges; but the comparison, under the circumstances, is not worth much. Seventy-two per cent. of the Heligoland specimens have a length of head over 24 per cent., and this would seem to show that these plaice were much longer in the head than any of my North Sea samples. But with regard to both these characters it must be remembered that the proportion of smaller specimens is much higher than in my samples, even when I consider only those of my specimens which are below the maxima sizes of Duncker's; and I conclude, therefore, that the head is much longer in the younger specimens. Indeed Duncker himself mentions the fact, stating that the 21 smaller females from Heligoland have a mean head-length of $24.9^{\circ}$ per cent., and the 24 larger, above $23.6 \mathrm{~cm}$. in length, a mean of only 23.7 per cent.

No comparison then is possible except in the characters which do not vary with age, namely, the numbers of fin-rays and gill rakers; 
and here Duncker does not give details, but simply states that the anal rays are mostly 51 to 55 , the dorsal 66 to 80 , and the gill-rakers mostly 10 or 11 .

In describing some specimens from the Baltic in this Journal* Mr. Holt referred to two spinulated specimens of the plaice, one from the south coast of Iceland, and one from the Great Fisher Bank in the North Sea. These specimens were among the collections left by Mr. Holt at Cleethorpes which came under my charge. I have examined them, and recorded their characters in the tabular lists appended to this paper. They are both males of large size, and except in the greater size of the Iceland specimen do not differ much from the largest of the males I have examined from beyond the Dogger Bank. In both specimens, as often occurs in the higher degrees of spinulation, this character is developed slightly on the head and body on the lower side. It never occurs on the fin-rays of the lower side, because there the scales are virtually obsolete. In the Iceland specimen the scales are spinulated all over the upper side of the body except below the pectoral fin, and also very slightly on the head and interspinous regions on the lower side. In the Fisher Bank specimen the spinulation extends all over both sides, also with the same exception, but is much weaker on the lower side than on the upper.

We have next to consider the plaice of the Baltic, samples of which are described by Duncker. Some of the specimens mentioned by Holt in the paper above cited came into my hands, and their characters are detailed in the tabular lists. The plaice of the Cattegat occupy geographically a somewhat intermediate position, and we may examine their characteristics before referring to the fish of the Baltic proper. Duncker remarks of the Cattegat plaice that they resemble those of Heligoland in all other respects, but differ in their enormous height of body and the shortness of the head. This is exactly what might be expected when we know that Duncker's sample from Heligoland consisted chiefly of very young and small specimens of a large-sized race. The males of Duncker's Cattegat sample were from 29.5 to $39.4 \mathrm{~cm}$. in total length, and 10 in number; of females there were 30 specimens 28.0 to $38.6 \mathrm{~cm}$. in length. They were thus nearly all larger than the largest of the Heligoland specimens. Four of the 10 males had no spinulation, two had degree 2 , and the rest degree 1 . One of the specimens without spinulation was $39.4 \mathrm{~cm}$. long, one $35.0 \mathrm{~cm}$., one $34.1 \mathrm{~cm}$., and one $29.5 \mathrm{~cm}$. According to Petersen's recordst some male plaice are immature in the Cattegat at $32.5 \mathrm{~cm}$., if not even at a larger size. But in none of my samples is a male specimen so large as $39.4 \mathrm{~cm}$. entirely without spinulation. I find it difficult to believe

* Vol. iii. p. $198 . \quad+$ Report of the Danish Biological Station, iv., for 1893. 
that plaice in the Cattegat are less spinulated when mature than those of the northern part of the North Sea, and think it probable that if a larger number of mature specimens from the former locality were examined they would be found to exhibit as great a development of spinulation. My specimens from beyond the Dogger Bank, being taken in deep water far from land, would naturally include few immature specimens, and male specimens in that condition even $35 \mathrm{~cm}$. in length might occur nearer shore. It must be pointed out that in my specimens from beyond the Dogger Bank degree 4 of spinulation only occurs in specimens over $40 \mathrm{~cm}$. in length, and we know from Petersen that male specimens above that length occur in the Cattegat, although Duncker did not obtain any. There is nothing in the results of Duncker concerning the numerical characters to distinguish the Cattegat plaice from those of the northern part of the North Sea examined by me.

Duncker examined 34 males and 48 females from the Western Baltic, taken in the neighbourhood of Niendorf and Kiel. The males were from $22 \cdot 6$ to $29 \cdot 7 \mathrm{~cm}$. long, the females from $22 \cdot 3$ to $31 \cdot 2 \mathrm{~cm}$. long (from 9 in. to little over 12 in.). We know from Holt's evidence that plaice of the Western Baltic at these sizes are all, or nearly all, sexually mature. The spinulation varies from degrees 2 to 5 according to my notation, and it is certain that it is more strongly developed than in the most spinulated of my samples, degree 1 occurring not infrequently in the females.

The height of the body, on the average 38 to 39 per cent. according to Duncker, seems to be no greater than in the Norfolk coast plaice, and scarcely so great as in the specimens from beyond the Dogger Bank. The length of the head is a little greater than in the northern part of the North Sea.

In the numerical characters there is a marked reduction: the dorsal rays rarely exceed 70 , though instances up to 75 and one of 78 occur. The ventral have a maximum of 60 , but are mostly from 46 to 55 . In this respect the form approximates to the character of the flounder. The number of the gill-rakers, however, is not greater than in North Sea plaice, but is on the contrary rather less, the number 12 not being exceeded, while in the Cattegat plaice the range of variation extends to 13 , as in my specimens from the North Sea.

The caudal peduncle, reaching sometimes 9 per cent., seems to be rather larger than in the North Sea.

Duncker describes four males and seven females from Greifswald, a place on the coast opposite the island of Rügen, and little more than 100 miles east of Kiel. On the evidence of these few specimens he concludes that the Greifswald plaice are on the whole different from those of the neighbourhood of Kiel, and approximate in several 
characters more to those of the North Sea, although it might be expected that, the locality being farther inwards in the Baltic, they would be more different from the plaice of the North Sea. I fail, however, to find in Duncker's description any differences to which such importance can be attributed, especially when the small number of specimens is considered. The four males are all small and young, 19.6 to $22.6 \mathrm{~cm}$., and this would partly account for the slightly lower height of body and greater length of head which Duncker mentions. The number of gill-rakers reaches 13 , but I fail to see any difference in the number of fin-rays. The degree of ciliation was 2 in all four male specimens, which is in accordance with their small size.

We see then that as far as the small amount of evidence at our disposal goes, the Baltic plaice are modified in the same direction as northern forms in the North Sea with regard to reduction of finrays and increase of spinulation, and to a much greater degree, while with regard to other characters, branchial rays, height of body and length of head, no very distinct differences are exhibited. In accordance with the reduction of the dorsal and ventral fins, the caudal peduncle is a little longer in the Baltic. It is interesting to notice that as we proceed northwards in the North Sea and Atlantic these modifications are associated with a great increase in total size, while in the Baltic there is an equally conspicuous decrease in size. This proves that the modifications are independent of the rate of growth, and therefore presumably of the amount of available food.

\section{The Relations between Local Variations and Specific Characters in the Plaice and Allied Species.}

The plaice and flounder are certainly very closely allied, and there is a third form which also differs but slightly from them. This third form is the Pleuronectes glacialis of Pallas. To study the relations of these three forms to one another we must take a general survey of all that is known concerning their whole distribution, and their variations in different parts of their habitats. The question has previously been discussed by Professor Smitt in his edition of the Scandinavian Fishes of Fries and Ekström, 1893, and by Duncker in the paper frequently cited above; but I have endeavoured, by examining additional evidence, to carry the investigation somewhat further.

Pleuronectes platessa. Southwards on the European coast the plaice seems to extend into the Mediterranean, although $\mathrm{I}$ have not been able to discover any very definite or detailed account of specimens from that sea. Smitt mentions its existence there, and Jordan and 
Goss * state that in the Museum of Comparative Zoology at Cambridge, Mass., there are a number of specimens from Trieste. Northwards the species extends to the White Sea. The evidence of this is that Smitt (loc. cit. p. 395) mentions a young plaice from Archangel which agrees with the form described by Pallas from Alaska and Kamtchatka under the name $P l$. quadrituberculatus, and by Steindachner under the name $P l$. Pallasii. Smitt regards these names as synonyms of $P l$. platessa. I do not admit the synonymy, and shall discuss the matter presently; but we may take it that the plaice extends to the White Sea. We have seen that it is abundant on the south coast of Iceland, and extends into the Baltic as far as Greifswald. But the plaice is not mentioned as occurring on the coast of Greenland, and is certainly absent from the east coast of North America. In the Pacific, however, forms which must be regarded as local varieties of the plaice, or very closely similar to it, reappear, and I will here give the history of these forms so far as it is known. The following is a list of the names under which the specimens have been described or mentioned :-

Pleuronectes quadrituberculatus, Pallas, Zoogr. Rosso-Asiat. iii. 423, 1811. Bean, Proc. U.S. Nat. Mus. 1881. Jordan and Gilbert, Synopsis Fish. N.A. 1882.

Parophrys quadrituberculatus, Günther, Cat. Fish. Brit. Mus. iv. p. 456 (copied).

Pleuronectes Pallasii, Steindachner, Ichth. Beitr., S.B., k. Akad. d. Wiss. Wien, lxxx. 1880.

Platessa quadrituberculata, Jordan and Goss, Flounders and Soles of Am. and Eur. Rep. U.S. Fish. Com. for 1886, pub. 1889.

The original description of quadrituberculatus by Pallas is as follows :-

Longitudo (11" 4 "') fere pedalis, latitudo summa cum pinnis $5^{\prime \prime} 11^{\prime \prime}$ sine pinnis $4 "$. Forma Flesi. Caput a latere oculato, fusco nigricante, tuberculis quatuor osseis, conicis obtusis prominentissimis, serie lineae laterali continua, quorum duo approximata anterius, tertium orbitae superioris postico margini contiguum, quartum maximum sinui branchiali adsidet. Linea lateralis in utroque latere a sinu branchiali levissime descendens, dehinc media rectissima speciem catenulae referens. Corpus glaberrimum, squamis subdistinctis obsoletissimis, cauda evidentius squamosa usque in radiorum intervalla. Opercula angulata. Pinnae pectorales rad. 11.subacutae; ventrales falcatae, rad. 6. P. dorsi ab orbitis incipiens rad. 70. P. ani pollicari a ventralibus distantia, rad. 51. Spina subcutanea ad anum. P. caudae rotundata, radiis 18 robustis bifidis.

* "Flounders and Soles of America and Europe." Report of U.S. Fish Commission for 1886 .

NEW SERIES, - VOL, IV, NO, 4, 
Now there is one point in this description which shows that the fish described was not a plaice at all. The four tubercles are not all behind the eyes, but only the third and fourth. Jordan and Goss describe their specimen as having about five tubercles above the operculum, and D. 68, A. 50. Bean gives no description, but states that his specimen was obtained at Kodiak; Jordan and Goss' specimen was also collected at Kodiak, and it is not clear whether it was the same specimen or whether there were two. Kodiak is a large island off the south coast of Alaska.

In the British Museum collection there is a single specimen identified as the quadrituberculatus of Pallas, and collected by the U.S. Fish Com. steamer Albatross. The identification is evidently that of the American naturalists, and the specimen leaves no doubt as to what were the characters of the fish so identified. The specimen was taken at Herendeen Bay, a bay on the north side of the Alaska Peninsula in $56^{\circ}$ north latitude and $161^{\circ}$ west longitude. The characters of the specimen are given in the tables below, and it will be seen that they are similar to those of a plaice. The body is rather broad and the head long, but in these respects the fish does not differ from the plaice of the North Sea to any important extent, and it must be remembered that we can make no very minute comparison between spirit specimens and fresh specimens. The tubercles on the head are, however, peculiar, and have a character which has not been observed in any Atlantic plaice; they are remarkably prominent, regularly conical, and uniform in size. In number and position they are like the tubercles of the plaice. The scales are like those of the plaice, cycloid and reduced so that they do not overlap. The lateral line is slightly elevated above the pectoral fin, but otherwise straight as in the plaice. The specimen is male, and the scales on the fin-rays are spinulated as in the majority of male plaice. The teeth seem to be rather smaller than in the North Sea plaice.

We find then that in the North Pacific, about the shores of Kodiak and the Alaska Peninsula, there is a local variety of the plaice, of which only a few specimens have been obtained, and that this form has been erroneously identified with the $P l$.quadrituberculatus of Pallas. The depth of water at which it was taken is not stated.

The only other record we have of a plaice-like fish in the North Pacific is Steindachner's account of Pl. Pallasii. The specimens so named came from Kamtchatka. The characters described are five depressed bony tubercles with blunt outer edges in a horizontal row between the eye and the lateral line. Dorsal rays, 63-68; anal, $48-53$; all the fin-rays scaleless; scales small, rounded. A figure is given showing the tubercles more rounded and less prominent than in the British Museum specimen.

South of Alaska and Kamtchatka we have no evidence that the 
Pacific form of the plaice exists. The flat-fishes of California and the west coast of America generally have been attentively studied by American zoologists, and are captured regularly for the market; but no specimens of this form have been noticed except the above, nor have any been discovered in Japan. The plaice-like form again is not known at present to extend further north than Herendeen Bay. Flat-fish have been collected at more northern places on the west coast of Alaska, but specimens of this form were not among them. It appears, therefore, that the species in the Pacific does not extend so far north or so far southwards as in the Atlantic; but, on the other hand, it is found on the west shores as well as on the east, whereas on the west side of the Atlantic it is absent.

Pleuronectes glacialis. Now to the northward, where the plaice disappears, the northern species, glacialis, is found in its stead, and this species occurs along all the northern coasts of Europe and America, and on the east coast of America. It presents local variations, and has been described under various names, but there is no doubt that it constitutes a single species, which in many respects is closely allied to the plaice. The following are the principal synonyms and references :-

Pleuronectes glacialis, Pallas, Zoogr. Rosso-Asiatica, iii. p. 424.

Pleuronectes cicatricosus, Pallas, ibid.

Pl. glacialis, Richardson, Voy. H.M.S. Herald, p. 166 (1852). Bean, Proc. U.S. Nat. Mus. 1881, p. 241 (Kotzebue Sound, Northern Alaska). Jordan and Gilbert, Synopsis Fish. N.A. Smitt, Scandinavian Fishes, 1893.

Platessa dvinensis, Lilljeborg, Svensk Vet. Akad. Handl, 1850.

Platessa glabra, Storer, Proc. Boston Soc. Nat. Hist. 1843, p. 130.

Liopsetta glabra, Gill, Proc. Acad. Nat. Sci. Philad. 1864.

Euchalarodus Putnami, Gill, Proc. Acad. Nat. Sci. Phil. 1864, p. 216.

Pleuronectes glaber, Goode and Bean, Proc. U.S. Nat. Mus. 1878, p. 347. Bean, ibid, p. 345.

Pleuronectes Franklinii, Günther, Cat. Fish. Brit. Mus. iv. 1862, p. 442 .

Pallas first described $P$. glacialis in 1773 , in his account of his journeys through various provinces of Russia; and in his larger work, published in 1811, repeated the description with but little modification. His specimens were taken in the Kara Sea and at the mouth of the river Obi. The chief characters given are the absence of spiny tubercles like those of the flounder; the ridge behind the eyes rough, but not divided into tubercles; the middle rays of the fins on the coloured side roughened with very minute spines; dorsal rays, 56; anal, 39. The upper side is also squamulis asperis granulatum, which probably means that the upper side was spinulated all over. 


\section{PECULIARITIES OF PLAICE FROM DIFFERENT FISHING GROUNDS.}

According to Pallas' description P. cicatricosus differs but little from glacialis. The specimens were collected in the sea between Kamtchatka and America. It is said to be more oblong, the length being three times the breadth without the fins. There is a rough osseous ridge behind the eyes. On the upper side the scales are far apart and scarcely projecting, except that every third or fifth over all the body and operculum has projecting setae on its margin; the middle fin-rays are also roughened with slight projecting points. Length of the specimen was $8 \frac{7}{12}$ inches, the breadth $2 \frac{10}{12}$ inches ; the number of dorsal rays 59 , anal 36. It is clear that the two forms thus described belong to the same species, and it is difficult to decide which was the more spinulated of the two.

Richardson states that he identified as the $P$. glacialis of Pallas a flounder taken in Bathurst's Inlet, which is on the north coast of North America. He afterwards obtained two specimens from the same region from Dr. Rae. They had all the characters described by Pallas, except the roughness of the middle rays of the dorsal and ventral fins. Richardson suggests for the first time that this may be a sexual peculiarity. He states that the parietal and suprascapular space-in other words, the post-ocular ridge-is divided into elevated granular surfaces; the scales are small and without spinules, except along the bases of the dorsal and ventral fins on the upper side. The length was 7.5 inches; the dorsal rays 58 , the ventral 43 .

In the British Museum collection there are two specimens identified with Richardson's species, which Dr. Günther named Franklinii, considering it distinct from glacialis. One of these is $22.8 \mathrm{~cm}$. long $(9$ inches), and according to the label came from Dr. Rae's collection. It has evidently been dried, and is moth-eaten; but the spinulated scales could be felt both on the fin-rays and on the body. The other specimen has also been dried, and was too hard and stiff for detailed examination; but this also has some spinulated scales on the fin-rays and the edge of the body. This specimen was labelled, "From the Haslar collection." Probably one of these specimens, or both, were those examined by Richardson, whose description of the spinulation in such case was incorrect. They are certainly of the same species as the glacialis and cicatricosus of Pallas.

The first description of specimens of the same species on the east coast of North America is that of Storer, in 1843, who gives it the name Platessa glabra. He says the body is perfectly smooth, and mentions no spinulated scales on the fins. But the number of the fin-rays (D. 54, A. 39), and the character of the post-ocular ridge (naked and rough, continued back to the superior angle of the operculum, where it is much larger, and terminates in an obtuse point), show 
that the fish in question resembled glacialis. The specimens were taken in Boston harbour.

In 1864 Gill gave the name Liopsetta glabra to Storer's species, and described a new species under the name Euchalarodus Putnami. The description summarised is as follows: D. 55-58, A. 39-40. Two specimens examined, obtained at Salem, Mass. Scales minute, distinct, immersed, each one on the coloured side with several slender teeth behind, directed outwards; on the light side of the body smooth or uniciliate. Lateral line straight. Head with an osseous ridge continued backwards, where it is expanded and separated from an oblique bony tubercle on the scapula. The name was given from the teeth, which were in a single series and movable.

In 1878 Tarleton H. Bean pointed out that the movable teeth and certain other minute characters, described by Gill in Euchalarodus, occurred also in $P$. glabra, and in the plaice, the teeth being movable in mature specimens in the breeding season; and that Euchalarodus Putnami was in fact the male of Liopsetta glabra, differing from it only in having more of the scales ciliated. The largest female in the gravid condition was $13 \frac{1}{2}$ inches long. In the Review of Flounders and Soles, 1889, Jordan and Goss confirm Bean's conclusions, and state that they see no difference by which Liopsetta glabra can be separated from $P$. glacialis. Specimens have been taken from Providence, Rhode Island, to Labrador, so that the southern limit of the species is $41^{\circ}$ north latitude.

Specimens identified as the $P$. glacialis or cicatricosus of Pallas have been taken in recent years by the U.S. Fishery steamer Albatross, on the west coast of Alaska, north of the Alaska Peninsula. The species is recorded by Bean as taken in Kotzebue Sound, but he gives no description; the same specimens, however, are briefly described by Jordan and Gilbert in their Synopsis of the Fishes of North America. It is there stated that the dorsal rays are 56, the anal 42 in number; that the scales are minute, imbedded, ctenoid in the males, smooth in the females. Now, the specimen in Bean's catalogue is numbered 27,947 , and this very specimen, bearing the same number and labelled from Kotzebue Sound, is now in the British Museum, received from the Smithsonian Institution. I examined it myself, and have recorded its characters in the lists below. It is a female, and yet is strongly ciliated on the fins and all over the body on the upper side, and only a little less on the lower side. On the coast of Alaska then the females are not without spinulation. In Jordan and Goss' Flounders and Soles a female of the same form from Kotzebue Sound is figured, and appears to be the same specimen which I have examined; but the number is quoted as 27,497 , probably a mere clerical error. 
There are two other specimens from Alaska in the British Museum, collected by the Albatross in the Nushagak River, and obtained from the U.S. Fish Commission. These also I have examined, and have recorded their characters below. Both are females, and immature; the smaller is ciliated on the fins, head, and central region of the upper side, but not on the interspinous regions; on the lower side it is also ciliated in the central region. The larger is ciliated all over the upper side, except the region covered by the pectoral, but not on the lower side.

Lilljeborg's specimens came from the mouth of the river Dwina, at Archangel, from which place Smitt also obtained specimens. Smitt considers Lilljeborg's species identical with Pallas' cicatricosus, but thinks that there are important differences between this and glacialis. He says that Pallas based his distinction on the deeper form of the body, and greater closeness of the scales in glacialis. The difference reappears, though modified by age and sex, between the specimens brought by Nordenskiöld from the north coast of Siberia, east of the Kara Sea, and the specimens brought from the White Sea. The specimens of the east coast of the United States, according to Smitt, also belong to cicatricosus. The narrower form, with fewer or smaller scales, therefore, according to Smitt, occurs in the White Sea, on the east coast of America, and in the Behring Sea; while the broader form extends along the Arctic shores of America and of Siberia; the glacialis is a purely Arctic form, while cicatricosus lives in a milder climate.

The evidence I have been able to examine does not enable me to test Smitt's conclusions with regard to the breadth of body or length of head very completely. I can only point out that the three specimens from the coast of Alaska, one of which at $18.3 \mathrm{~cm}$. was mature, agree fairly closely with the proportions given by Smitt for cicatricosus, and at the same time are not markedly narrower or longer in the head than many of the female plaice from the northern part of the North Sea. The male glacialis examined by Smitt were longer than the cicatricosus, all females, which he examined, and may have been older, which would to some extent account for their greater breadth and shorter heads. Smitt does not discuss the spinulation of the scales, and does not even mention that this is on the east coast of America a sexual character. In the two specimens from the north coast of North America which I have examined, as far as can be judged from their unsatisfactory condition, the spinulation is not greater than in male plaice from the North Sea, but their sex is unknown. The three specimens from the coast of Alaska are all females, and more spinulated than most of the male plaice from beyond the Dogger Bank. 
In these specimens of glacialis, therefore, spinulation is undoubtedly more developed than in the most spinulated plaice, even than in those of the Baltic. On the other hand, the descriptions of the American naturalists do not tend to show that the forms named by them Liopsetta Putnami and glabra are more spinulated than the plaice of the Baltic. It is clear, however, that all the local forms of glacialis differ very distinctly from the plaice in the smaller number of fin-rays and the character of the post-ocular ridge, which is granulated, terminating posteriorly in a pear-shaped elevation of the skull-bone, succeeded by a slight elevation of the post-temporal bone. These two elevations correspond to the two posterior tubercles of the plaice, but are not prominent enough to be called tubercles.

We have seen that in the White Sea both plaice and glacialis occur; but this is the limit of the plaice eastwards and of glacialis westwards. The two species similarly succeed one another on the coast of Alaska, the northern limit of the plaice being the northern shore of the Alaskan Peninsula, which also forms the southern limit of glacialis. Glacialis therefore is strictly a geographical representative of the plaice. So far as we know it is, like the plaice, a marine form, not ascending rivers higher than their mouths. There are remarkable and interesting differences in the limits between the two species in different parts of the world, which are found on examination to correspond very closely to differences of temperature depending on ocean currents. In a map of the world by John Bartholomew the seas closed by ice in winter in the north are distinguished, and the distribution of the species glacialis corresponds almost exactly to the area of these seas. Owing to the north-eastern trend of the coast of Scandinavia the Gulf Stream, or north-easterly warm current in the Atlantic, travels far to the north and east, producing an ice-free sea as far as the entrance of the White Sea. Thus the plaice extends on the east side of the Atlantic beyond the North Cape, latitude about $72^{\circ}$, while on the east side of the Pacific its northern limit is about $56^{\circ}$. The westward projection of Alaska stops the north-easterly progress of the warm current in the Pacific, so-that Behring Sea is closed by ice in winter, and here we have the form glacialis. Again, the open warmer sea in the Atlantic embraces the south coast of Iceland, where the plaice is not only abundant, but reaches its maximum size; while the glacial sea extends along the coasts of Greenland, down the west coast of America to Nova Scotia. The southerly cold current, known as the Labrador current, passes down from the north along the coast of Labrador and the east coast of North America, and this fact corresponds to the southerly extension of the glacialis form to Cape Cod, and the entire absence of the plaice. It appears that glacialis is taken 
on the coast of the United States chiefly, if not exclusively, in winter; and we may conclude that the low temperature of the water in winter excludes the plaice, while the high summer temperature prevents the extension of glacialis further to the south.

Pleuronectes flesus. We have next to consider the flounder, which is distinguished from the other two species most conspicuously by the character of the scales, many of which are more reduced than in the plaice, while others on particular parts of the body have taken on a peculiar development, and have been enlarged into prominent thorny tubercles. These tubercles are most constantly present in a single row along the bases of the dorsal and ventral fins, and are also usually present on the head and about the lateral line, while in certain forms they are developed over nearly the whole of the skin of the upper side.

The species occurs on the east side of the Atlantic all along the coasts of Europe-from the White Sea on the north to the Black Sea at the extremity of the Mediterranean. At different regions within these limits it exhibits local variations. Duncker examined samples from various parts of the Baltic and from the North Sea. In criticising his results we must take into account the fact that the flounder is essentially an estuarine fish, often ascending rivers into fresh water, and only descending to the sea in order to spawn.

In the Baltic the flounder extends much further than the plaice, and generally exhibits a much greater development of tubercles than on the coasts of the North Sea. Duncker examined samples from Königsberg, Greifswald, Niendorf, and Kiel. From Königsberg he had 20 males and 8 females; the males from $19.0 \mathrm{~cm}$. to $28.2 \mathrm{~cm}$. in length, the females from 23.3 to $28.2 \mathrm{~cm}$. They were remarkable for their very rough squamation, great height of body, very short heads, and conspicuous red spots, approximating to the coloration of the plaice. There were crowded small tubercles over the whole of the upper side, on the blind side at least along the lateral line, on the abdomen, and on the interspinous region. The average height of body was 39.9 per cent. in the males, 41.1 per cent. in the females. The length of head was 22.3 per cent., and also less in the males. The number of fin-rays was higher than in other Baltic samples, the mean of the dorsal being $58 \cdot 1$, of the ventral $40 \cdot 7$. The number of gill-rakers was 11-18.

The Greifswald sample consisted of 14 males, 15 females; the males in length $16.5 \mathrm{~cm}$. to $26.0 \mathrm{~cm}$., the females $15.8 \mathrm{~cm}$. to $34.6 \mathrm{~cm}$. In these the squamation was less rough; the height of body less, 37.8 per cent. on the average; the head longer. It seems to me all these differences are sufficiently explained by the greater proportion of younger and smaller specimens. The mean numbers of the dorsal and ventral 
rays was a little lower, but in such a small number of specimens the difference does not seem of great importance.

From Niendorf and Kiel there were 26 males, 30 females; the length of the males was $20.1 \mathrm{~cm}$. to $38.5 \mathrm{~cm}$., of the females $20.8 \mathrm{~cm}$. to $30.6 \mathrm{~cm}$. According to Duncker the squamation and coloration are intermediate between the Greifswald and Königsberg forms. The Niendorf males were narrow, and these were few in number and of large size; the length of head slightly greater than in the Königsberg sample, a fact very probably due to the greater proportion of females. The mean of the numbers of dorsal fin-rays was only a little over 56, that of the ventral the same as in the Greifswald sample.

Duncker's North Sea specimens were collected near Heligoland, therefore in the sea; at Cuxhaven at the mouth of the Elbe; and at Hamburg. Considering the migratory habits of the species, it is obvious that these must be considered as belonging to one region, and Duncker admits that they are difficult to distinguish. The Heligoland specimens are stated to have been obtained in July and August, and it is surprising that flounders should be found abundantly in the sea at that time of the year. But perhaps the fact is explained by the shallowness of the water, and the proximity of the two large rivers Elbe and Weser. We find, however, as might be expected, that the Heligoland specimens are the largest and doubtless the oldest. The numbers and sizes are :-

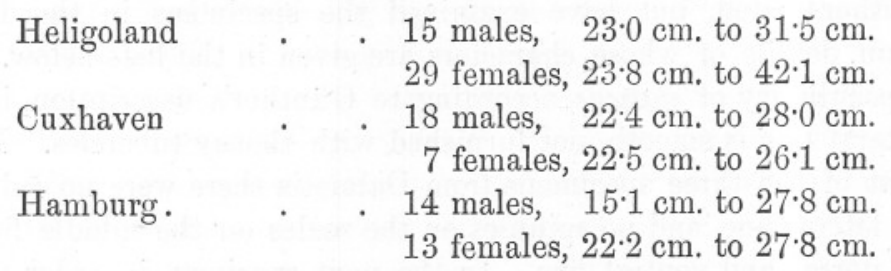

In these North Sea flounders the rough tubercles are limited to the bases of the fins and the lateral line, while the scales on the rest of the body are smooth and cycloid; the tubercles occur chiefly at the anterior part of the lateral line, and in the middle region of the bases of the fins. The number of gill-rakers is on the average two or three higher than in the Baltic (15 to 22). The fin-rays are more numerous. The body is narrower; but in the length of head no constant difference was evident.

I cannot altogether agree with Duncker in his views with regard to the comparison between the variations of the plaice and flounder in the North Sea and Baltic. He considers that the two forms approach one another to some extent in the Baltic more than they do in the North Sea. In the two cases we find a similar modification in the greater roughness of the scales, in the greater breadth of the body, and the reduction in the number of fin-rays. The number of gill-rakers 
is higher in the flounder than in the plaice, and is reduced in the Baltic; in this respect the modification does reduce the difference between the species, and the difference in the coloration is also reduced in the Baltic. The length of the caudal peduncle in the flounder is reduced in the Baltic, while in the plaice it is somewhat increased. The three modifications which are in the same direction are those which take place in passing from south to north; and it is a fact that the Baltic is colder than the North Sea. On the other hand, it seems to me probable that as the Baltic is fresher than the North Sea the flounder there may live less in the rivers, and therefore, on the whole, in salter water, while the plaice lives in fresher, and that this may have something to do with the brighter red spots in the flounder in the Baltic.

The flounder in the Mediterranean has been described under different names in the belief that it formed distinct species. The synonyms, or names given to these local forms, are :-

Pleuronectes luscus, Pallas, Zoogr. Rosso-Asiat. iii. p. 427. 1811 (Black Sea).

Platessa glabra, Rathke, Fauna der Krym., p. 352. 1837 (Crimea).

Platessa passer, Bonaparte, Fauna Italica, Pesc. 1838-40.

Pleuronectes italicus, Günther, Cat. Fish. Brit. Mus. iv. 1862 (Dalmatia).

I have not taken the trouble to go through the descriptions given by the authors cited, but have examined the specimens in the British Museum, details of whose characters are given in the lists below. The chief peculiarity of italicus, according to Günther's description, is that the lateral line is smooth, not furnished with thorny tubercles. In the smallest of the three specimens from Dalmatia there were no tubercles on the lateral line, and no spinules on the scales on the middle fin-rays of the dorsal and ventral fins. In the next specimen in order of size there were spinules on 22 of the dorsal and ventral rays, no tubercles on the lateral line or on the head. In the third specimen two tubercles were found at the anterior end of the lateral line, but only one spinule was detected on the dorsal fin, none on the ventral. Spinules on the fins are not present in the North Sea flounders. The number of the fin-rays is not greater than in the North Sea flounders, but is as great, and therefore greater than in the flounders of the Baltic. The height of body also resembles that of the North Sea specimens, while the length of the caudal peduncle is as short as in the Baltic. The length of head shows nothing remarkable.

Of the local form described as luscus there were seven specimens in the British Museum: four from Constantinople and the Bosphorus, three from the Black Sea. In all these there were a number of tubercles along the front part of the lateral line, but these were not 
very abundant or very prominent. The spinules on the fin-rays were also more numerous and more regular. The fin-rays are scarcely different from those of the Dalmatia form, but the body is higher and the head apparently a little longer; these, however, are differences of age, the body being higher in the larger specimens, the head longer in the smaller. In the Black Sea specimens, as in those from Dalmatia, the tubercles along the bases of the fins are present, more developed in the former. Again, we find here that the greater development of tubercles corresponds to a colder climate; the Black Sea is considerably colder, at least in winter, than the Adriatic. The presence of spinulated scales on the fin-rays, as in the plaice, is remarkable.

On the northern coast of the eastern hemisphere the flounder is not known to occur further east than the White Sea. Smitt states that Lieut. Sandeberg brought specimens from the White Sea in which the body was entirely smooth, with the exception of the spinous tubercles at the bases of the fin-rays, and a few on the head and near the lateral line. They were described as a distinct species under the name Pleuronectes Bogdanovii; but quite similar forms may, according to Smitt, be found in the Baltic. These were apparently individual variations, and it is not clear whether or not the flounder on the whole is as strongly spinous in the White Sea as in the Baltic.

The flounder is not included in Lütken's Fishes of Greenland, and is not mentioned as occurring on the north-east coast of North America. Yet there is a form, scarcely distinct as a species, in the Pacific, remarkable chiefly for the extensive development of spiny tubercles, but in the character of these tubercles, and in other respects, very closely similar to the European flounder. The chief difference is, that according to the descriptions of Jordan and Goss there are no cycloid scales in the Pacific form, to which they actually give a distinct generic name, Platichthys stellatus. This form extends from Point Conception on the coast of California, latitude $34^{\circ}$, to Coronation Gulf on the Arctic coast of America, which is north of latitude $70^{\circ}$, and not very far west of Hudson's Bay. It is difficult to understand why the flounder-like form should be absent on the intervening coasts, or in the intervening rivers, between the north-west coast of America and the coast of Europe. On the Asiatic side of the Pacific the form stellatus extends southwards to Saghalien, and indeed from the descriptions appears to be the same species as Pleuronectes asperrimus of Japan.

Smitt suggests in one passage that the forms which culminate in the plaice and flounder started from one of the three limanda (dab) glacialis or cicatricosus, and considers the latter two varieties to be diverging in the same directions as flesus and platessa. Duncker, on the other hand, considers the plaice the oldest form on account of its 
cycloid scales, and to have come from the far north; to have formed the variety glacialis on the Arctic coasts, and then with this variety to have entered the Baltic, where the plaice gave rise to the Baltic form of plaice, and the glacialis to the flounder.

The conclusions at present suggested by the facts to my own mind are as follows: The plaice is by no means necessarily the original form, as there is reason for holding that the original form of these and other flat-fishes had ctenoid scales of the usual kind, as in the dab. The facts show that the species glacialis is the Arctic form, the flounder the fluviatile form of the plaice. Whatever the causes which led to the reduction of the scales in the plaice, it is certain that the ctenoid condition is more developed in the Arctic form: this form is also without tubercles and has fewer fin-rays. There are objections to the view, which Duncker appears to take, that the development of the tubercles in the flounder is a further stage in the development of the spinules on the scales in the plaice and in glacialis. The most spinulated scales occur in the two latter forms on the fin-rays and in the interspinous regions, while in the flounder it is precisely in these two regions that the scales are most rudimentary, and along the base of the fins and along the lateral line the scales are developed into spiny tubercies. As we have seen, the spinules on the fin-rays are retained to some extent only in the smoothest flounders, those of the Mediterranean, while in those of more northern latitudes the fin-rays are scaleless. Thus we might almost say that the condition of the flounder was due to the further progress of a modification in the same direction as that of the plaice, that the ctenoid scales first underwent reduction, and then when they had become rudimentary some of them in particular parts of the body developed into tubercles. This view, however, is not consistent with the fact that both plaice and flounder become rougher, their calcified skin armature more developed, in the north than in the south. The correct interpretation of this fact is evidently that the development of scales has taken a different direction in the flounder, and that in both directions cold, or some condition accompanying a northern climate, has the effect of producing enlargement of the structures connected with the scales. It is not possible at present to see any connection between the fact that the flounder lives in rivers, and the peculiar development of its tubercles, nor can we see any advantage to the fish in the possession of these structures.

We do not find that the correspondence which is observed between climate and development of spines on the scales in the plaice and flounder exists when we compare the species of flat-fishes with one another. The sole, for instance, is a distinctly southern form, and its scales are strongly ctenoid all over the body. The dab, however, is 
more closely allied to the plaice and flounder, and also has ctenoid scales all over its body, except the area covered by the pectoral fin; ctenoid scales extend also on to the fin-rays. Now it is not a fact that the dab inhabits more northern regions than the plaice, and still less than glacialis. On the contrary the dab and plaice are constantly taken together on the same ground. The dab extends on the European coast from the Bay of Biscay to the Kara Sea, and is plentiful on the south coast of Iceland, and is found in the Baltic at least as far east as Gothland. On the American side of the Atlantic the dab lives in the same latitudes as glacialis, but in a slightly different form, described by American naturalists as a distinct species, under the name Limanda ferruginea. In the North Pacific, however, we do find that the local form of the dab, like the local form of the flounder, is rougher than in other parts of the world. This form is described under the name Limanda aspera, and extends from Sitka and Saghalien to Wrangel Island off the coast of Siberia. Thus, although we find here again that rougher scales in the same species characterise the more northern forms, and appear to indicate a direct influence of climate, we do not find that northern and southern species are constantly distinguished by a similar difference in the character of the scales. The occurrence of spinulation as a secondary sexual character, developing in the males, as such characters generally do, only when maturity is reached, is peculiar to the plaice, and at present we have no evidence that, as Duncker suggests, the character is of any importance in the relations of the sexes. 


\section{PECULIARITIES OF PLAICE FROM DIFFERENT FISHING GROUNDS.}

\section{A.-TABLES SHOWING THE CHARACTERS OBSERVED IN EACH SPECIMEN EXAMINED.}

The specimens of each sex in each locality are arranged in order of size.

The Height of Body, Length of Head, Length of Caudal Peduncle, and Length of Caudal Fin, are expressed in hundredths of the Total Length. The Total Length is measured from the extremity of the lower jaw to the end of the middle ray of the caudal fin.

The degrees of spinulation of the scales, often called ciliation, are as follows :-

1. On the fin-rays only: the numbers of spinulated dorsal rays and ventral rays are added together in one column; the degree on the body is shown in the next column.

2. On the fin-rays, and also on the head in front of the preopercular bone.

3. Also on the operculum.

4. Also on the body in the region of the interspinous bones.

5. Also on a greater extent of the body. 
PECULIARITIES OF PLAICE FROM DIFFERENT FISHING GROUNDS. 345

Locality: Plymouth-grounds near Eddystone.

Males. Total Number, 15.

\begin{tabular}{|c|c|c|c|c|c|c|c|c|c|c|c|c|c|c|c|c|}
\hline $\begin{array}{l}\text { Length, } \\
\mathrm{cm} .\end{array}$ & & $\begin{array}{l}\text { Ht. of } \\
\text { Body. }\end{array}$ & & $\begin{array}{l}\text { Length } \\
\text { f Head. }\end{array}$ & & $\begin{array}{l}\text { au. } \\
\text { ed. }\end{array}$ & & $\begin{array}{l}\text { Caun. } \\
\text { Fin. }\end{array}$ & & & $\begin{array}{l}\text { es. Gill- } \\
\text { Rakers. }\end{array}$ & $\begin{array}{l}\text { D. } \\
\text { Rays. }\end{array}$ & $\begin{array}{c}\text { A. } \\
\text { Rays. }\end{array}$ & $\begin{array}{l}\text { Ciliated } \\
\text { Rays. }\end{array}$ & $\begin{array}{l}\text { Cil. } \\
\text { Body. }\end{array}$ & $\begin{array}{l}\text { Matu- } \\
\text { rity. }\end{array}$ \\
\hline $29 \cdot 3$ & $\ldots$ & 40 & $\ldots$ & 23 & $\ldots$ & 5 & $\ldots$ & 20 & $\ldots$ & 5 & $\ldots$ & 71 & ... 54 & $\begin{array}{c}\text { Com. } \\
\text {. }\end{array}$ & 0 & $\ldots \quad \mathrm{i}$ \\
\hline $29 \cdot 4$ & $\ldots$ & 39 & $\ldots$ & 23 & ... & 5 & $\ldots$ & 19 & $\ldots$ & 5 & $\ldots 11$. & 74 & 55 & $\ldots$ & $\ldots$ & $\mathrm{m}$ \\
\hline $30 \cdot 2$ & $\ldots$ & 38 & ... & 22 & $\ldots$ & 6 & $\ldots$ & 19 & $\ldots$ & 5 & $\ldots 10$. & ... 73 & $\ldots \quad 56$ & ... 36 & 2 & $\ldots \mathrm{m}$ \\
\hline $32 \cdot 2$ & $\ldots$ & 36 & $\ldots$ & 22 & $\ldots$ & 5 & $\ldots$ & 18 & $\ldots$ & 3 & 9 . & $\ldots 76$ & .. 56 & ... 37 & $\ldots$ & $\ldots$ \\
\hline $32 \cdot 3$ & $\ldots$ & 37 & $\ldots$ & 21 & $\ldots$ & 5 & $\ldots$ & 19 & $\ldots$ & 4 & $\ldots 11$. & $\ldots 72$ & .. 53 & ... 37 & 2 & $\ldots$ \\
\hline $32 \cdot 4$ & $\ldots$ & 39 & $\ldots$ & 21 & $\ldots$ & 6 & $\ldots$ & 18 & $\ldots$ & 5 & $\ldots 10$. & .. 74 & $\ldots 55$ & ... 31 & ... 0 & $\ldots$ \\
\hline $32 \cdot 5$ & $\ldots$ & 38 & $\ldots$ & 23 & $\ldots$ & 6 & ... & 20 & $\ldots$ & 6 & $\ldots 11$. & ... 70 & ... 52 & .. 58 & .. 4 & $\ldots$ \\
\hline $32 \cdot 8$ & $\ldots$ & 40 & $\ldots$ & 21 & $\ldots$ & 6 & ... & 19 & $\ldots$ & 5 & .. 10 . & ... 67 & $\ldots \quad 53$ & ... 40 & $\ldots 0$ & . \\
\hline $33 \cdot 3$ & $\ldots$ & 39 & $\ldots$ & 23 & $\ldots$ & 6 & $\ldots$ & 19 & $\ldots$ & 6 & ... 10 . & .. 72 & ... 52 & $\cdots$ & ... 0 & $\ldots$ \\
\hline $33 \cdot 5$ & $\ldots$ & 37 & $\ldots$ & 22 & $\ldots$ & 5 & $\ldots$ & 19 & $\ldots$ & 5 & $\ldots$ & ... 71 & ... 53 & $\ldots \quad 55$ & ... 3 & $\ldots$ \\
\hline $33 \cdot 7$ & $\ldots$ & 38 & $\ldots$ & 21 & $\ldots$ & 5 & $\ldots$ & 17 & ... & 5 & .. 10 . & $\ldots 77$ & ... 58 & .. 40 & .. 2 & $\ldots \mathrm{m}$ \\
\hline 33.9 & $\ldots$ & 41 & $\ldots$ & 22 & $\ldots$ & 6 & $\ldots$ & 18 & $\ldots$ & 5 & $\ldots$ & .. 72 & .. 54 & $\ldots 50$ & $\ldots \quad 2$ & $\ldots$ ? \\
\hline $37 \cdot 4$ & $\ldots$ & 39 & $\cdots$ & 22 & $\ldots$ & 5 & $\cdots$ & 18 & $\ldots$ & 5 & ... 10 . & .. 73 & ... 53 & ... 43 & $\ldots 2$ & $\ldots$ \\
\hline $38 \cdot 7$ & .. & 37 & ... & 21 & $\ldots$ & 5 & $\cdots$ & 19 & $\ldots$ & 4 & ... 10 & .. 75 & ... 56 & ... 37 & ... 0 & $\ldots$ \\
\hline $42 \cdot 4$ & $\ldots$ & 35 & $\ldots$ & 21 & $\ldots$ & 5 & $\cdots$ & 18 & $\ldots$ & 3 & .. 11 & .. 69 & ... 52 & ... 40 & ... 0 & .. \\
\hline
\end{tabular}

Females. Total Number, 21.

\begin{tabular}{|c|c|c|c|c|c|c|c|c|c|c|c|c|c|c|c|c|c|c|c|c|}
\hline 95 & $\cdots$ & 38 & $\cdots$ & 23 & $\cdots$ & 6 & $\cdots$ & 18 & $\cdots$ & 5 & $\ldots$ & 9 & $\ldots$ & 75 & $\ldots$ & 56 & $\cdots$ & - & $\ldots-$ & $\cdots$ \\
\hline$\cdot 1$ & $\ldots$ & 38 & $\ldots$ & 22 & $\ldots$ & 5 & $\ldots$ & 19 & $\cdots$ & 5 & $\cdots$ & 10 & $\ldots$ & 75 & $\ldots$ & 57 & $\ldots$ & - & $\ldots-$ & $\cdots$ \\
\hline 2 & $\cdots$ & 40 & $\cdots$ & 21 & $\ldots$ & 5 & $\ldots$ & 19 & $\cdots$ & 5 & $\ldots$ & 10 & $\ldots$ & 75 & $\ldots$ & 55 & $\ldots$ & - & $\ldots-$ & ... \\
\hline & $\ldots$ & 37 & $\ldots$ & 23 & $\ldots$ & 6 & $\ldots$ & 18 & $\ldots$ & 5 & $\ldots$ & 10 & $\ldots$ & 74 & $\ldots$ & 55 & $\cdots$ & - & $\ldots-$ & $\cdots$ \\
\hline & $\ldots$ & 41 & $\ldots$ & 24 & $\ldots$ & 5 & $\ldots$ & 9 & $\ldots$ & 5 & $\ldots$ & 10 & $\ldots$ & 72 & $\ldots$ & 5 & $\ldots$ & - & $\ldots-$ & $\cdots$ \\
\hline & $\cdots$ & 38 & $\cdots$ & 2 & $\cdots$ & 6 & $\ldots$ & 0 & $\ldots$ & 5 & . & 9 & $\ldots$ & 6 & $\ldots$ & 6 & $\ldots$ & - & $\ldots-$ & . \\
\hline & $\ldots$ & 39 & $\ldots$ & 22 & $\ldots$ & 5 & $\cdots$ & 18 & $\ldots$ & 5 & $\ldots$ & 10 & $\ldots$ & 75 & $\ldots$ & 3 & $\cdots$ & - & $\ldots-$ & 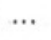 \\
\hline & $\cdots$ & 39 & $\ldots$ & 21 & $\cdots$ & 6 & $\cdots$ & 19 & $\cdots$ & 5 & $\cdots$ & $?$ & $\ldots$ & 75 & $\ldots$ & 5 & $\cdots$ & - & $\ldots-$ & $\ldots$ \\
\hline & $\ldots$ & 38 & $\cdots$ & 22 & $\ldots$ & 5 & $\cdots$ & 19 & $\ldots$ & 5 & $\ldots$ & 10 & $\ldots$ & 4 & $\ldots$ & 6 & $\ldots$ & - & $\ldots-$ & $\cdots$ \\
\hline & $\ldots$ & 38 & $\ldots$ & 22 & $\ldots$ & 6 & $\ldots$ & 20 & $\ldots$ & 5 & $\ldots$ & 10 & .. & 74 & $\ldots$ & 5 & $\ldots$ & - & $\ldots-$ & $\cdots$ \\
\hline & $\ldots$ & 38 & $\ldots$ & 22 & $\ldots$ & 5 & $\ldots$ & 17 & $\cdots$ & 5 & $\ldots$ & 9 & $\ldots$ & 5 & $\cdots$ & 6 & $\ldots$ & - & $\ldots-$ & *. \\
\hline 4 & $\cdots$ & 38 & $\ldots$ & 23 & $\ldots$ & 6 & $\ldots$ & 23 & $\ldots$ & 5 & $\cdots$ & 10 & $\ldots$ & 66 & $\ldots$ & 53 & $\cdots$ & - & $\ldots-$ & . \\
\hline 5 & $\ldots$ & 40 & $\ldots$ & 21 & $\ldots$ & 7 & $\ldots$ & 17 & $\ldots$ & 7 & $\ldots$ & 10 & $\ldots$ & 71 & $\ldots$ & 51 & $\cdots$ & - & $\ldots-$ & $\ldots$ \\
\hline$\cdot 1$ & $\cdots$ & 41 & $\cdots$ & 22 & $\ldots$ & 6 & $\cdots$ & 18 & $\cdots$ & 6 & $\cdots$ & 10 & $\ldots$ & 74 & $\cdots$ & 54 & $\cdots$ & - & $\ldots-$ & $\ldots$ \\
\hline$\cdot 4$ & $\ldots$ & 40 & $\ldots$ & 23 & $\cdots$ & 5 & $\cdots$ & 18 & $\cdots$ & 5 & $\cdots$ & 10 & $\cdots$ & 72 & $\cdots$ & 52 & $\cdots$ & - & $\cdots-$ & $\cdots$ \\
\hline 6 & $\cdots$ & 38 & $\ldots$ & 22 & $\ldots$ & 6 & $\ldots$ & 18 & $\ldots$ & 4 &.. & 10 & $\ldots$ & 74 & $\ldots$ & 56 & $\cdots$ & - & $\ldots-$ & $\cdots$ \\
\hline$\cdot 0$ & $\ldots$ & 38 & $\ldots$ & 22 & $\ldots$ & 5 & $\ldots$ & 18 & $\cdots$ & 5 & $\ldots$ & 10 & $\ldots$ & 72 & $\ldots$ & 55 & $\cdots$ & - & $\ldots-$ & $\cdots$ \\
\hline 0 & $\ldots$ & 37 & $\ldots$ & 23 & $\cdots$ & 5 & $\cdots$ & 20 & $\ldots$ & 5 & $\ldots$ & 11 & $\cdots$ & 75 & $\cdots$ & 56 & $\cdots$ & - & $\ldots-$ & $\cdots$ \\
\hline 0.5 & $\cdots$ & 36 & $\cdots$ & 21 & $\cdots$ & 6 & $\cdots$ & 18 & $\ldots$ & 5 & * & 11 & & 72 & $\cdots$ & 56 & $\cdots$ & - & $\ldots-$ & $\cdots$ \\
\hline 6 & $\ldots$ & 38 & $\ldots$ & 21 & $\cdots$ & 5 & $\cdots$ & 17 & $\cdots$ & 5 & $\cdots$ & 10 & $\cdots$ & 76 & $\cdots$ & 57 & $\ldots$ & - & $\ldots-$ & $\cdots$ \\
\hline · 3 & $\ldots$ & 39 & $\ldots$ & 23 & $\ldots$ & 6 & $\ldots$ & 18 & $\ldots$ & 5 & $\ldots$ & 9 & $\ldots$ & 68 & $\ldots$ & 51 & $\ldots$ & - & $\ldots-$ & $\ldots$ \\
\hline
\end{tabular}




\section{Locality: Brown Ridges, North Sea.}

\section{Males. Total Number, 52.}

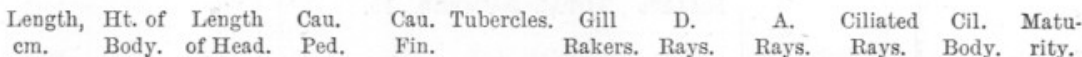
$\begin{array}{lllllllllllllllllllllll}22 \cdot 1 & \ldots & 36 & \ldots & 24 & \ldots & 5 & \ldots & 18 & \ldots & 5 & \ldots & 11 & \ldots & 72 & \ldots & 53 & \ldots & 0 & \ldots & 0 & \ldots & \text { i }\end{array}$ $\begin{array}{lllllllllllllllllllllll}24.9 & \ldots & 37 & \ldots & 22 & \ldots & 5 & \ldots & 21 & \ldots & 5 & \ldots & 10 & \ldots & 68 & \ldots & 51 & \ldots & 0 & \ldots & 0 & \ldots & \mathrm{i}\end{array}$ $\begin{array}{lllllllllllllllllllllll}26 \cdot 2 & \ldots & 39 & \ldots & 21 & \ldots & 6 & \ldots & 18 & \ldots & 5 & \ldots & 11 & \ldots & 74 & \ldots & 55 & \ldots & 42 & \ldots & 0 & \ldots & \text { ? }\end{array}$ $\begin{array}{lllllllllllllllllllllll}26.9 & \ldots & 40 & \ldots & 22 & \ldots & 6 & \ldots & 18 & \ldots & 5 & \ldots & 9 & \ldots & 73 & \ldots & 55 & \ldots & 29 & \ldots & 0 & \ldots & \mathrm{i} \text { ? }\end{array}$ $\begin{array}{lllllllllllllllllllllll}27 \cdot 5 & \ldots & 39 & \ldots & 22 & \ldots & 6 & \ldots & 17 & \ldots & 5 & \ldots & 10 & \ldots & 73 & \ldots & 54 & \ldots & 17 & \ldots & 0 & \ldots & \mathrm{i} \text { ? }\end{array}$ $\begin{array}{lllllllllllllllllllllll}27 \cdot 5 & \ldots & 38 & \ldots & 22 & \ldots & 6 & \ldots & 18 & \ldots & 5 & \ldots & 9 & \ldots & 74 & \ldots & 56 & \ldots & 9 & \ldots & 0 & \ldots & \text { i ? }\end{array}$ $\begin{array}{lllllllllllllllllllllll}27 \cdot 7 & \ldots & 37 & \ldots & 21 & \ldots & 6 & \ldots & 18 & \ldots & 5 & \ldots & 9 & \ldots & 71 & \ldots & 53 & \ldots & 35 & \ldots & 0 & \ldots & \text { ? }\end{array}$ $\begin{array}{lllllllllllllllllllllll}28 \cdot 1 & \ldots & 39 & \ldots & 22 & \ldots & 6 & \ldots & 18 & \ldots & 5 & \ldots & 10 & \ldots & 72 & \ldots & 53 & \ldots & 36 & \ldots & 2 & \ldots & -\end{array}$ $\begin{array}{llllllllllllllllllllllll}28 \cdot 3 & \ldots & 39 & \ldots & 22 & \ldots & 6 & \ldots & 18 & \ldots & 5 & \ldots & 10 & \ldots & 78 & \ldots & 57 & \ldots & 37 & \ldots & 0 & \ldots & -\end{array}$ $\begin{array}{lllllllllllllllllllllll}28 \cdot 4 & \ldots & 39 & \ldots & 22 & \ldots & 6 & \ldots & 19 & \ldots & 5 & \ldots & 9 & \ldots & 76 & \ldots & 55 & \ldots & 34 & \ldots & 2 & \ldots & \mathrm{m}\end{array}$ $\begin{array}{lllllllllllllllllllllll}28.5 & \ldots & 38 & \ldots & 23 & \ldots & 5 & \ldots & 19 & \ldots & 5 & \ldots & 10 & \ldots & 78 & \ldots & 55 & \ldots & 26 & \ldots & 0 & \ldots & -\end{array}$ $\begin{array}{lllllllllllllllllllllll}28 \cdot 6 & \ldots & 39 & \ldots & 22 & \ldots & 5 & \ldots & 17 & \ldots & 5 & \ldots & 10 & \ldots & 73 & \ldots & 56 & \ldots & 42 & \ldots & 2 & \ldots & \mathrm{m}\end{array}$ $\begin{array}{lllllllllllllllllllllll}28.8 & \ldots & 37 & \ldots & 22 & \ldots & 5 & \ldots & 19 & \ldots & 5 & \ldots & 9 & \ldots & 73 & \ldots & 53 & \ldots & 32 & \ldots & 0 & \ldots & -\end{array}$ $\begin{array}{lllllllllllllllllllllll}28.8 & \ldots & 38 & \ldots & 21 & \ldots & 6 & \ldots & 18 & \ldots & 5 & \ldots & 10 & \ldots & 69 & \ldots & 53 & \ldots & 42 & \ldots & 0 & \ldots & -\end{array}$ $\begin{array}{lllllllllllllllllllllll}29 \cdot 2 & \ldots & 40 & \ldots & 22 & \ldots & 5 & \ldots & 17 & \ldots & 6 & \ldots & 9 & \ldots & 73 & \ldots & 52 & \ldots & 36 & \ldots & 2 & \ldots & -\end{array}$ $\begin{array}{lllllllllllllllllllllll}29.3 & \ldots & 37 & \ldots & 22 & \ldots & 5 & \ldots & 18 & \ldots & 5 & \ldots & 10 & \ldots & 75 & \ldots & 54 & \ldots & 39 & \ldots & 0 & \ldots & -\end{array}$ $\begin{array}{lllllllllllllllllllllll}29 \cdot 5 & \ldots & 38 & \ldots & 22 & \ldots & 6 & \ldots & 18 & \ldots & 5 & \ldots & 10 & \ldots & 73 & \ldots & 52 & \ldots & 39 & \ldots & 2 & \ldots & \mathrm{m}\end{array}$ $\begin{array}{lllllllllllllllllllllll}29 \cdot 6 & \ldots & 39 & \ldots & 22 & \ldots & 6 & \ldots & 18 & \ldots & 5 & \ldots & 10 & \ldots & 71 & \ldots & 51 & \ldots & 21 & \ldots & 0 & \ldots & -\end{array}$

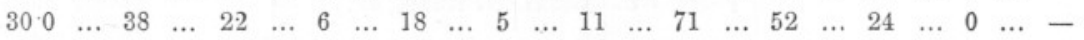
$\begin{array}{llllllllllllllllllllllll}30.0 & \ldots & 40 & \ldots & 23 & \ldots & 6 & \ldots & 19 & \ldots & 5 & \ldots & 10 & \ldots & 72 & \ldots & 53 & \ldots & 10 & \ldots & 0 & \ldots & -\end{array}$ $\begin{array}{lllllllllllllllllllllll}30 \cdot 1 & \ldots & 37 & \ldots & 22 & \ldots & 6 & \ldots & 18 & \ldots & 5 & \ldots & 10 & \ldots & 76 & \ldots & 56 & \ldots & 42 & \ldots & 2 & \ldots & \mathrm{m}\end{array}$ $\begin{array}{llllllllllllllllllllll}30 \cdot 1 & \ldots & 39 & \ldots & 21 & \ldots & 6 & \ldots & 17 & \ldots & 5 & \ldots & 12 & \ldots & 72 & \ldots & 55 & \ldots & 32 & \ldots & 0 & \ldots\end{array}$ $\begin{array}{lllllllllllllllllllllll}30.3 & \ldots & 37 & \ldots & 22 & \ldots & 5 & \ldots & 18 & \ldots & 5 & \ldots & 10 & \ldots & 74 & \ldots & 55 & \ldots & 40 & \ldots & 2 & \ldots & -\end{array}$ $\begin{array}{lllllllllllllllllllllll}30.3 & \ldots & 40 & \ldots & 22 & \ldots & 6 & \ldots & 18 & \ldots & 6 & \ldots & 11 & \ldots & 75 & \ldots & 55 & \ldots & 25 & \ldots & 2 & \ldots & \mathrm{m}\end{array}$ $\begin{array}{lllllllllllllllllllllll}30 \cdot 7 & \ldots & 40 & \ldots & 22 & \ldots & 5 & \ldots & 17 & \ldots & 5 & \ldots & 10 & \ldots & 74 & \ldots & 55 & \ldots & 37 & \ldots & 0 & \ldots & -\end{array}$ $\begin{array}{lllllllllllllllllllllll}30.7 & \ldots & 38 & \ldots & 23 & \ldots & 5 & \ldots & 22 & \ldots & 5 & \ldots & 10 & \ldots & 70 & \ldots & 51 & \ldots & 9 & \ldots & 0 & \ldots & -\end{array}$ $\begin{array}{lllllllllllllllllllllll}31 \cdot 2 & \ldots & 38 & \ldots & 22 & \ldots & 7 & \ldots & 17 & \ldots & 5 & \ldots & 10 & \ldots & 73 & \ldots & 55 & \ldots & 47 & \ldots & 3 & \ldots & \mathrm{m}\end{array}$ $\begin{array}{lllllllllllllllllllllll}31.6 & \ldots & 41 & \ldots & 22 & \ldots & 6 & \ldots & 18 & \ldots & 5 & \ldots & 9 & \ldots & 77 & \ldots & 58 & \ldots & 33 & \ldots & 0 & \ldots & \mathrm{m}\end{array}$ $\begin{array}{lllllllllllllllllllllll}31.8 & \ldots & 38 & \ldots & 22 & \ldots & 5 & \ldots & 18 & \ldots & 5 & \ldots & 10 & \ldots & 70 & \ldots & 55 & \ldots & 48 & \ldots & 2 & \ldots & -\end{array}$ $\begin{array}{lllllllllllllllllllllll}32 \cdot 0 & \ldots & 38 & \ldots & 21 & \ldots & 6 & \ldots & 21 & \ldots & 6 & \ldots & 9 & \ldots & 73 & \ldots & 54 & \ldots & 37 & \ldots & 2 & \ldots & \mathrm{m}\end{array}$ $\begin{array}{lllllllllllllllllllllll}32 \cdot 1 & \ldots & 38 & \ldots & 23 & \ldots & 6 & \ldots & 19 & \ldots & 5 & \ldots & 9 & \ldots & 72 & \ldots & 53 & \ldots & 41 & \ldots & 2 & \ldots & \mathrm{m}\end{array}$ $\begin{array}{lllllllllllllllllllllll}32 \cdot 3 & \ldots & 39 & \ldots & 22 & \ldots & 6 & \ldots & 16 & \ldots & 5 & \ldots & 9 & \ldots & 73 & \ldots & 55 & \ldots & 47 & \ldots & 2 & \ldots & -\end{array}$ $\begin{array}{lllllllllllllllllllllll}32 \cdot 4 & \ldots & 38 & \ldots & 21 & \ldots & 6 & \ldots & 18 & \ldots & 6 & \ldots & 9 & \ldots & 70 & \ldots & 52 & \ldots & 41 & \ldots & 2 & \ldots & \mathrm{m}\end{array}$ $\begin{array}{lllllllllllllllllllllll}32.9 & \ldots & 36 & \ldots & 21 & \ldots & 6 & \ldots & 18 & \ldots & 6 & \ldots & 9 & \ldots & 70 & \ldots & 53 & \ldots & 34 & \ldots & 0 & \ldots & -\end{array}$ $\begin{array}{lllllllllllllllllllllll}32 \cdot 9 & \ldots & 39 & \ldots & 22 & \ldots & 5 & \ldots & 20 & \ldots & 5 & \ldots & 10 & \ldots & 69 & \ldots & 50 & \ldots & 35 & \ldots & 2 & \ldots & -\end{array}$ $\begin{array}{llllllllllllllllllllllll}33 \cdot 2 & \ldots & 37 & \ldots & 21 & \ldots & 6 & \ldots & 18 & \ldots & 5 & \ldots & 10 & \ldots & 73 & \ldots & 53 & . . & 36 & \ldots & 2 & \ldots & -\end{array}$ $\begin{array}{lllllllllllllllllllllll}33.4 & \ldots & 39 & \ldots & 22 & \ldots & 6 & \ldots & 18 & \ldots & 5 & \ldots & 10 & \ldots & 68 & \ldots & 50 & \ldots & 26 & \ldots & 2 & \ldots & \mathrm{m}\end{array}$ $\begin{array}{llllllllllllllllllllllll}33.8 & \ldots & 36 & \ldots & 20 & \ldots & 4 & \ldots & 17 & \ldots & 5 & \ldots & 11 & \ldots & 71 & \ldots & 55 & \ldots & 39 & \ldots & 3 & \ldots & -\end{array}$ $\begin{array}{lllllllllllllllllllllll}33.8 & \ldots & 36 & \ldots & 21 & \ldots & 4 & \ldots & 17 & \ldots & 5 & \ldots & 9 & \ldots & 75 & \ldots & 58 & \ldots & 47 & \ldots & 2 & \ldots & -\end{array}$ $\begin{array}{llllllllllllllllllllllll}34 \cdot 1 & \ldots & 36 & \ldots & 20 & \ldots & 6 & \ldots & 16 & \ldots & 6 & \ldots & 10 & \ldots & 76 & \ldots & 53 & \ldots & 25 & \ldots & 2 & \ldots & -\end{array}$ $\begin{array}{lllllllllllllllllllllll}34 \cdot 2 & \ldots & 36 & \ldots & 22 & \ldots & 5 & \ldots & 19 & \ldots & 5 & \ldots & 10 & \ldots & 75 & \ldots & 57 & \ldots & 0 & \ldots & 0 & \ldots & -\end{array}$ $\begin{array}{lllllllllllllllllllllll}34 \cdot 2 & \ldots & 39 & \ldots & 22 & \ldots & 5 & \ldots & 19 & \ldots & 5 & \ldots & 11 & \ldots & 73 & \ldots & 52 & \ldots & 37 & \ldots & 0 & \ldots & \mathrm{m}\end{array}$ $\begin{array}{lllllllllllllllllllllll}34 \cdot 6 & \ldots & 40 & \ldots & 21 & \ldots & 7 & \ldots & 19 & \ldots & 5 & \ldots & 9 & \ldots & 75 & \ldots & 55 & \ldots & 17 & \ldots & 0 & \ldots & \mathrm{m}\end{array}$ $\begin{array}{lllllllllllllllllllllll}34.8 & \ldots & 37 & \ldots & 22 & \ldots & 6 & \ldots & 18 & \ldots & 5 & \ldots & 11 & \ldots & 68 & \ldots & 51 & \ldots & 26 & \ldots & 0 & \ldots & -\end{array}$ 


\section{MALES-continued.}

Length, Ht. of Length Cau. Cau. Tubereles. Gill D. A. Ciliated Cil. Matu$\mathrm{cm}$. Body. of Head. Ped. Fin. Rakers. Rays. Rays. Rays. Body. rity. $\begin{array}{lllllllllllllllllllllll}34 \cdot 8 & \ldots & 40 & \ldots & 20 & \ldots & 5 & \ldots & 18 & \ldots & 5 & \ldots & 9 & \ldots & 67 & \ldots & 51 & \ldots & 39 & \ldots & 2 & \ldots & -\end{array}$ $\begin{array}{llllllllllllllllllllll}35 \cdot 1 & \ldots & 36 & \ldots & 20 & \ldots & 6 & \ldots & 17 & \ldots & 5 & \ldots & 9 & \ldots & 76 & \ldots & 56 & \ldots & 35 & \ldots & 3 & \ldots\end{array}$ $\begin{array}{lllllllllllllllllllllll}35 \cdot 4 & \ldots & 35 & \ldots & 20 & \ldots & 6 & \ldots & 19 & \ldots & 5 & \ldots & 11 & \ldots & 74 & \ldots & 56 & \ldots & 44 & \ldots & 2 & \ldots & -\end{array}$ $\begin{array}{lllllllllllllllllllllll}35 \cdot 7 & \ldots & 38 & \ldots & 22 & \ldots & 6 & \ldots & 17 & \ldots & 6 & \ldots & 11 & \ldots & 76 & \ldots & 56 & \ldots & 2 & \ldots & 0 & \ldots & -\end{array}$ $\begin{array}{lllllllllllllllllllllll}35 \cdot 8 & \ldots & 39 & \ldots & 20 & \ldots & 7 & \ldots & 18 & \ldots & 7 & \ldots & 10 & \ldots & 71 & \ldots & 52 & \ldots & 41 & \ldots & 2 & \ldots & -\end{array}$ $\begin{array}{lllllllllllllllllllllll}35 \cdot 8 & \ldots & 39 & \ldots & 20 & \ldots & 5 & \ldots & 18 & \ldots & 5 & \ldots & 11 & \ldots & 69 & \ldots & 54 & \ldots & 36 & \ldots & 3 & \ldots & \mathrm{m}\end{array}$ $\begin{array}{llllllllllllllllllllllll}36.0 & \ldots & 40 & \ldots & 21 & \ldots & 6 & \ldots & 17 & \ldots & 7 & \ldots & 10 & \ldots & 74 & \ldots & 55 & \ldots & 39 & \ldots & 2 & \ldots & -\end{array}$ $\begin{array}{lllllllllllllllllllllll}36.8 & \ldots & 41 & \ldots & 22 & \ldots & 5 & \ldots & 18 & \ldots & 6 & \ldots & 10 & \ldots & 75 & \ldots & 58 & \ldots & 41 & \ldots & 2 & \ldots & \mathrm{m}\end{array}$

Females. Total Number, 57.

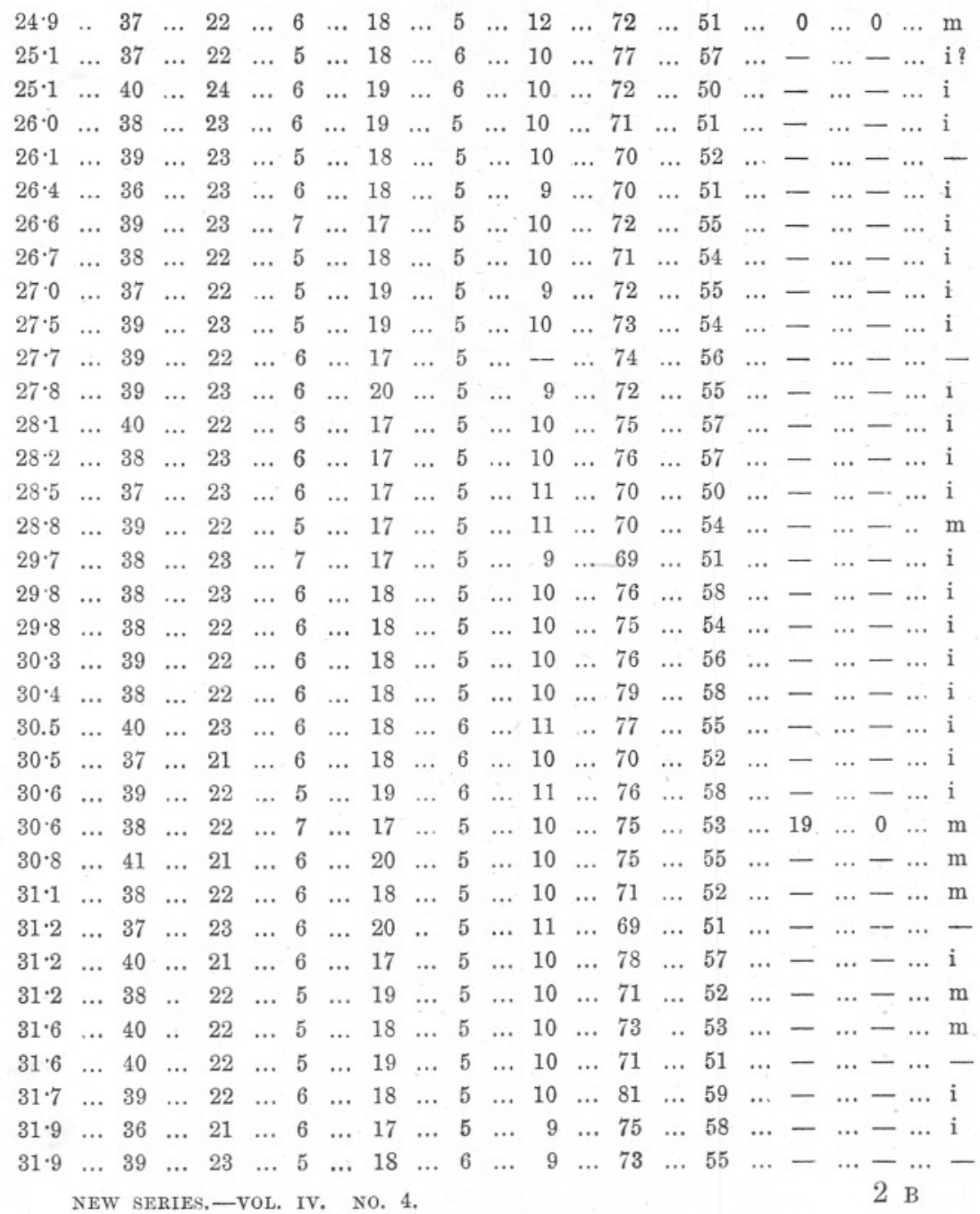


348 PECULIARITIES OF PLAICE FROM DIFFERENT FISHING GROUNDS.

Locality: Brown Ridges, North Sea.

Females-continued.

\begin{tabular}{|c|c|c|c|c|c|c|c|c|c|c|c|c|c|c|}
\hline $\begin{array}{l}\text { Length, } \\
\text { cm. }\end{array}$ & $\begin{array}{l}\text { Ht. of } \\
\text { Body. }\end{array}$ & & $\mathrm{He}$ & Ped. & & $\begin{array}{l}\text { Cau. } \\
\text { Fin. }\end{array}$ & & & $\begin{array}{l}\text { Gill } \\
\text { Rakers. }\end{array}$ & $\begin{array}{l}\text { D. } \\
\text { Rays. }\end{array}$ & $\begin{array}{c}\text { A. } \\
\text { Rays. }\end{array}$ & $\begin{array}{c}\text { Ciliated } \\
\text { Rays. }\end{array}$ & $\begin{array}{l}\text { Cil. } \\
\text { Body }\end{array}$ & $\begin{array}{l}\text { Matu- } \\
\text { y. rity. }\end{array}$ \\
\hline $31 \cdot 9$ & ... 41 & $\cdots$ & 22 & .. 5 & $\cdots$ & 17 & $\cdots$ & 5 & ... 10 & 74 & $\ldots \quad 55$ & $\ldots-$ & $\ldots-$ & 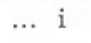 \\
\hline 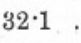 & .. 38 & & 23 & $\ldots \quad 5$ & . & 18 & - & 5 & .. 10 & 70 & .. 52 & .. & $\ldots-$ & . \\
\hline 4 & . 39 & & 23 & ... 6 & $\ldots$ & 17 & .. & 6 & $\ldots \quad 11$ & 74 & ... 52 & . - & $\ldots-$ & 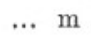 \\
\hline 6 & . 37 & " & 23 & ... 6 & $\cdots$ & 18 & $\cdot$ & . & $\ldots \quad 11$ & $\ldots 76$ & $\ldots .55$ & $\ldots-$ & $\ldots-$ & 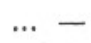 \\
\hline 3 & . 36 & $\cdots$ & 23 & $\ldots 6$ & $\ldots$ & 17 & $\cdots$ & 5 & .. 10 & 79 & .. 57 & - & $\ldots-$ & 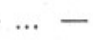 \\
\hline 4 & 39 & . & 23 & $\ldots$ & $\ldots$ & 18 & & 6 & ... 10 & $\ldots$ & .. 50 & $\ldots-$ & $\ldots-$ & . \\
\hline$\cdot 9$ & .. 36 & ... & 21 & $\ldots 5$ & $\cdots$ & 18 &.. & 5 & .. 10 & .. & $\ldots \quad 55$ & $\ldots-$ & $\ldots-$ & $\ldots$ \\
\hline 0 & .. 40 & & 22 & $\ldots 5$ & $\cdots$ & 18 & $\cdots$ & 5 & ... 10 & $\ldots$ & ... 51 & $\ldots-$ & $\ldots-$ & $\ldots$ \\
\hline 2 & 3 & $\cdots$ & 22 & $\ldots$ & $\ldots$ & 18 & $\ldots$ & 5. & $\ldots$ & 79 & $\ldots \quad 57$ & $\ldots-$ & $\ldots-$ & \\
\hline$: 3$ & 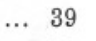 & .. & 21 & $\ldots$ & $\ldots$ & 18 & $\ldots$ & 6 & $\begin{array}{ll}\ldots & 10\end{array}$ & 68 & $\ldots \quad 53$ & - & $\ldots-$ & \\
\hline 3 & 39 & ... & 22 & $\ldots$ & $\ldots$ & 17 & $\ldots$ & 5 & ... 11 & $\ldots 74$ & $\ldots 54$ & $\ldots-$ & $\ldots-$ & $\ldots$ \\
\hline 4.8 & .. 36 & ... & 20 & $\ldots \quad 5$ & $\cdots$ & 17 & $\ldots$ & 5 & .. 10 & $\ldots 74$ & ㄷ 55 & $\ldots-$ & $\ldots-$ & $\ldots$ \\
\hline 1.8 & .. 40 & .. & 22 & $\ldots 6$ & $\cdots$ & 18 & $\ldots$ & 5 & .. 10 & $\ldots 7$ & $\ldots \quad 54$ & $\ldots-$ & $\ldots-$ & $\ldots$ \\
\hline$\cdot 1$ & .. & . & 21 & $\ldots$ & $\ldots$ & 18 & $\cdot$ & 6 & $\ldots$ & . & $\ldots 56$ & $\ldots-$ & $\ldots-$ & \\
\hline 2 & .. 39 & & 22 & $\ldots 6$ & . & 18 & $\ldots$ & 5. & $\ldots \quad 11$ & $\ldots 77$ & $\ldots \quad 57$ & $\ldots-$ & $\ldots-$ & $\ldots$ \\
\hline $36 \cdot 4$ & .. 39 & 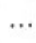 & 23 & $\ldots 6$ & $\cdots$ & 19 & $\cdots$ & 6. & .. 10 & 68 & .. 52 & $\ldots-$ & $\ldots-$ & \\
\hline $7 \cdot 0$ & .. 38 & $\ldots$ & 22 & $\ldots 6$ & .. & 17 & $\cdot$ & 6 & .. 11 & 77 & $\ldots \quad 55$ & $\ldots-$ & $\ldots-$ & \\
\hline $7 \cdot 3$ & .. 39 & $\cdots$ & 21 & $\ldots$ & * & 19 & $\ldots$ & 5 & .. 10 & $\ldots$ & .. 55 & $\ldots-$ & $\ldots-$ & \\
\hline$\cdot 7$ & .. 39 & $\ldots$ & 22 & $\ldots 6$ & . & 18 & . & 5 & .. 10 & $\ldots$ & $\ldots \quad 54$ & $\ldots-$ & $\ldots-$ & $-\ldots$ \\
\hline $8 \cdot 4$ & .. 41 & & 23 & $\ldots 5$ & $\cdots$ & 19 & $\ldots$ & 5 & $\ldots \quad 13$ & .. 64 & .. 48 & $\ldots-$ & $\ldots-$ & $-\ldots$ \\
\hline $38 \cdot 9$ & . 39 & & 23 & $\ldots 5$ & .. & 18 & ... & 5 & .. 10 & $\ldots 76$ & .. 56 & $\ldots-$ & $\ldots-$ & $-\ldots$ \\
\hline $9 \cdot 4$ & 39 & & 22 & $\ldots 5$ & .. & 18 & $\ldots$ & 5 & .. 11 & $\ldots 76$ & $\ldots \quad 55$ & ... $\quad-$ & $\ldots-$ & \\
\hline
\end{tabular}




\section{Locality: Norfolk Coast.}

Males. Total Number, 49.

\begin{tabular}{|c|c|c|c|c|c|c|c|c|c|c|c|c|}
\hline $\mathrm{m}$. & $\begin{array}{l}\text { h, Ht. of } \\
\text { Body. }\end{array}$ & $\begin{array}{l}\text { Length } \\
\text { of Head }\end{array}$ & $\begin{array}{l}\text { Cau. } \\
\text { l. Ped. }\end{array}$ & & $\begin{array}{l}\text { Cau. } \\
\text { Fin. }\end{array}$ & & $\begin{array}{l}\text { s. Gill } \\
\text { Rakers. }\end{array}$ & $\begin{array}{c}\text { D. } \\
\text { Rays. }\end{array}$ & $\begin{array}{c}\text { A. } \\
\text { Rays. }\end{array}$ & $\begin{array}{c}\text { Ciliated } \\
\text { Rays. }\end{array}$ & $\begin{array}{c}\text { d Cil. } \\
\text { Body }\end{array}$ & $\begin{array}{l}\text { Matu } \\
\text { ly. rity. }\end{array}$ \\
\hline 0.7 & . 45 & $\ldots \quad 23$ & .. 6 & $\ldots$ & 19 & .. 5 & $\ldots 10$ & & & & & $\ldots-$ \\
\hline $23 \cdot 5$ & $\ldots \quad 40$ & $\begin{array}{ll}\ldots & 24\end{array}$ & $\ldots 6$ & $\ldots$ & 17 & $\ldots 5$ & ... 10 & $\ldots 73$ & $\ldots 55$ & 21 & 0 & - \\
\hline$\cdot 8$ & ... 39 & $\begin{array}{ll}\ldots & 24\end{array}$ & $\ldots 6$ & $\ldots$ & 20 & $\ldots 4$ & $\begin{array}{ll}\ldots & 9\end{array}$ & .. 69 & ... 53 & ... & 0 & 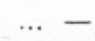 \\
\hline 16 & ... 38 & ... 23 & ... 5 & & 19 & $\ldots 6$ & $\ldots 10$. & $\begin{array}{ll}\ldots & 73\end{array}$ & 53 & & 0 & - \\
\hline$\cdot 9$ & .. 38 & .. 23 & ... 6 & . & 18 & $\ldots 5$ & $\ldots 10$ & .. 67 & $\ldots 51$ & .. 38 & & \\
\hline $5 \cdot 2$ & $\ldots \quad 42$ & $\ldots \quad 22$ & $\ldots 6$ & . & 17 & $\ldots 5$ & $\ldots 10$. & $\ldots 74$ & ... 54 & $\ldots 37$ & 0 & $\ldots-$ \\
\hline 5 & .. 36 & ... 22 & $\ldots 6$ & $\ldots$ & 18 & $\ldots 5$ & $\ldots 10$. & $\begin{array}{ll}\ldots & 79\end{array}$ & $\ldots 56$ & $\ldots \quad 27$ & $\ldots 0$ & - \\
\hline •8 & ... 40 & $\begin{array}{ll}\ldots & 22\end{array}$ & ... 6 & $\ldots$ & 20 & .. 5 & $\begin{array}{lll}\ldots & 9\end{array}$ & ... 71 & $\ldots 54$ & $\cdots_{\text {mencin }}^{\text {Com }}$ & $\cdots-$ & - \\
\hline 1 & .. 37 & $\ldots \quad 23$ & $\ldots 6$ & & 19 & $\ldots 5$ & $\ldots 11$. & ... 70 & & & 0 & $\ldots i$ \\
\hline 6 & $\ldots 40$ & $\begin{array}{ll}\ldots & 22\end{array}$ & $\ldots 5$ & $\ldots$ & 19 & $\ldots 4$ & $\ldots 8$. & ... 72 & $\ldots 52$ & $\ldots$ & 0 & $\ldots-$ \\
\hline $7 \cdot 1$ & $\ldots 37$ & $\ldots \quad 22$ & $\ldots 6$ & $\ldots$ & 18 & $\ldots 5$ & $\ldots 10$. & $\ldots 72$ & $\ldots 55$ & $\ldots 15$ & $\ldots 0$ & $\ldots \mathrm{i}$ \\
\hline 3 & ... 36 & $\ldots \quad 22$ & ... 6 & $\cdots$ & 19 & $\ldots 5$ & $\ldots 10$ & ... 67 & ... 49 & $\ldots 38$ & $\ldots 2$ & $\ldots-$ \\
\hline 5 & $\ldots 38$ & $\ldots \quad 22$ & ... 6 & $\ldots$ & 19 & $\ldots 4$ & $\ldots \quad 12$. & $\ldots 78$ & $\ldots 57$ & $\ldots \quad 17$ & $\begin{array}{ll}\ldots & 0\end{array}$ & $\ldots-$ \\
\hline 88 & $\ldots 38$ & $\ldots \quad 22$ & $\ldots 5$ & $\ldots$ & 18 & $\ldots 7$ & $\ldots 10$. & ... 70 & $\ldots 55$ & $\ldots 43$ & 2 & - \\
\hline $29 \cdot 2$ & ... 40 & $\ldots \quad 21$ & $\ldots 6$ & $\ldots$ & 19 & ... 5 & $\ldots 11$ & $\begin{array}{ll}\ldots & 74\end{array}$ & $\ldots 57$ & $\ldots 37$ & $\ldots 0$ & $\ldots-$ \\
\hline $29 \cdot 3$ & ... 39 & .. 22 & $\ldots 7$ & $\ldots$ & 18 & .. 5 & $\ldots 10$. & .. 70 & $\ldots \quad 52$ & $\ldots \quad 27$ & $\ldots 0$ & $\ldots-$ \\
\hline 5 & .. 42 & ... 23 & $\ldots 7$ & $\ldots$ & 17 & $\ldots$ & $\ldots \quad 9$. & $\ldots$ & ... 54 & ... 38 & $\ldots 2$ & $\ldots-$ \\
\hline .5 & .. 40 & $\ldots \quad 22$ & $\ldots 6$ & $\ldots$ & 2 & $\ldots 6$ & $\ldots \begin{array}{lll}\ldots 1 & 11\end{array}$ & $\begin{array}{ll}\ldots & 69\end{array}$ & $\ldots 53$ & $\ldots \quad 35$ & $\ldots 0$ & $\ldots-$ \\
\hline $30 \cdot 0$ & ... 38 & ... 22 & $\ldots 6$ & $\ldots$ & 1 . & .. 5 & ... 10 . & $\ldots 73$ & $\ldots \quad 56$ & ... 35 & $\ldots 2$ & - \\
\hline $30 \% 3$ & .. 38 & 23 & ... 6 & 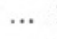 & 1 & $\ldots 5$ & $\ldots \quad 9$. & .. 76 & $\ldots \quad 56$ & $\ldots$ & $\ldots 0$ & $\therefore-$ \\
\hline $30 * 6$ & *. & .. 24 & $\ldots 5$ & $\ldots$ & 17 & $\ldots 5$ & $\ldots 10$. & $\ldots \quad 69$ & ... 51 & ... 10 & $\ldots 0$ & $\ldots-$ \\
\hline $31 \cdot 5$ & $\ldots$ & $\ldots$ & ... 6 & $\ldots$ & 1 . & $\ldots 5$ & $\begin{array}{lll}\ldots & 9\end{array}$ & $\ldots \quad 72$ & .. 52 & .. 27 & 0 & - \\
\hline 326 & ... 3 & ... 2 & .. 5 & $\ldots$ & 2 & .. 5 & $\ldots 10$. & .. 72 & .. 53 & .. 44 & $\ldots 2$ & - \\
\hline 53 & $\ldots 3$ & $\begin{array}{ll}\ldots & 2\end{array}$ & $\ldots 6$ & 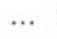 & 2 & 5 & $\ldots$ & $\ldots 71$ & $\ldots 53$ & ... 42 & 2 & - \\
\hline 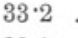 & $\ldots 37$. & ... 21 & $\ldots 6$ & $\ldots$ & 18 & $\ldots 5$ & $\ldots 10$. & .. 71 & $\ldots 53$ & ... 34 & .. 2 & $\ldots-$ \\
\hline 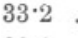 & $\ldots 3$ & $\cdots$ & $\ldots 6$ & $\ldots$ & 1 . & $\ldots 6$ & $\begin{array}{lll}\ldots & 9\end{array}$ & $\ldots 74$ & $\ldots 54$ & $\ldots \quad 0$ & ... 0 & $\ldots-$ \\
\hline $33 \cdot 3$ & ... 4 & .. 2 & .. 6 & $\ldots$ & 1 & ... & $\ldots 11$. & .. 7 & $\ldots 56$ & $\ldots 33$ & $\ldots 2$ & $\ldots \mathrm{i}$ \\
\hline $34 \% 2$ & ... 38 & ... 22 & 5 & 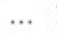 & 18 & 5 & $\ldots 1$ & .. 76 & $\ldots 57$ & $\ldots 3$ & $\ldots 0$ & i \\
\hline ( & $\ldots 37$. & $\ldots \quad 22$ & $\ldots 5$ & $\ldots$ & 18 & ... 6 & $\ldots 10$ & $\ldots \quad 72$ & .. 54 & $\ldots 16$ & $\begin{array}{ll}\ldots & 0\end{array}$ & .. - \\
\hline 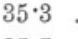 & $\ldots 4$ & $\ldots \quad 22$ & $\ldots 5$ & $\ldots$ & 1 & $\ldots 6$ & $\ldots 10$. & $\ldots \quad 76$ & 57 & ... 23 & $\begin{array}{ll}\ldots & 0\end{array}$ & $\ldots$ \\
\hline $35 \cdot 5$ & $\ldots 3$ & . 2 & $\ldots 5$ & 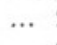 & 2 & $\ldots 5$ & $\ldots 1$ & $\ldots 7$ & $\ldots$ & $\ldots 4$ & ... 0 & $\ldots$ \\
\hline $5^{\circ}$ & $\ldots .39$ & .. 22 & $\ldots 6$ & $\ldots$ & 1 & 6 & $\ldots 1$ & ... 74 & $\ldots 58$ & & $\ldots 2$ & $\ldots-$ \\
\hline 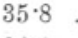 & $\ldots 3$ & ... 23 & $\ldots 6$ & $\ldots$ & 1 . & $\ldots 5$ & $\ldots 10$. & $\ldots 76$ & $\ldots 57$ & $\ldots_{\text {mencing }}^{\text {Com }}$ & $g_{1} \cdots 2$ & $\ldots \mathrm{i}$ \\
\hline 36.0 & $\cdot 3$ & 2 & 6 & 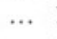 & 1 & 5 & $\begin{array}{ll}\ldots & 10\end{array}$ & $\ldots 73$ & & 49 & 3 & $\ldots$ \\
\hline 36.5 & 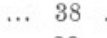 & 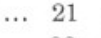 & 6 & & , & 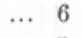 & $\ldots 10$, & $\ldots$ & $\ldots$ & & 0 & $\cdots$ \\
\hline $36 \cdot 5$ & $\ldots \quad 38$ & $\ldots \quad 2$ & ... 6 & $\ldots$ & 1 & 5 & $\ldots$ & $\ldots \quad 73$ & $\ldots 56$ & $\ldots$ & $\begin{array}{ll}\ldots & 0\end{array}$ & $\ldots \mathrm{m}$ \\
\hline 36.8 & ... 38 & .. 22 & $\ldots 6$ & $\ldots$ & 18 & $\cdots$ & $\ldots .10$ & .. 76 & $\ldots 56$ & ... 41 & $\ldots 2$ & $\ldots$ \\
\hline & -1 & $\ldots 2$ & 6 & & 2 & 4 & $\ldots \quad 9$ & 75 & $\ldots$ & $\ldots 8$ & 2 & 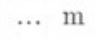 \\
\hline $37 \cdot 0$ & 車 & . 21 & 6 & & 1 & 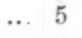 & $\ldots 1$ & $\ldots 75$ & $\ldots$ & 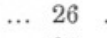 & 2 & 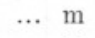 \\
\hline $37 \cdot 7$ & $\begin{array}{ll}\ldots & 39\end{array}$ & $\cdots$ & ... 6 & $\ldots$ & 2 & 4 & $\ldots \begin{array}{lll}\ldots & 10\end{array}$ & ... 71 , & $\ldots 54$ & ... 32 & $\ldots 3$ & $\ldots \mathrm{m}$ \\
\hline $38 \cdot 3$ & $\begin{array}{ll}\ldots & 39\end{array}$ & .. 21 & ... 6 & 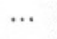 & $1\}$ & 5 & $\ldots-$. & .. 73 & $\ldots 56$ & ... 37 & ... 2 & $\ldots$ \\
\hline 38 & 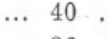 & 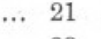 & 5 & & 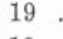 & 5 & ... 10 . & 7 & $\ldots$ & $\cdots$ & ... 0 & 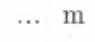 \\
\hline 39 & 36 & 2 & 5 & & 1 & 3 & 1 & 7 & & 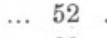 & ... 2 & $\ldots$ \\
\hline 40.4 & . 40 & .. 21 & $\ldots 6$ & & 1 & & $\ldots 10$. & .. 71 & $\ldots 54$ & & $\ldots 3$ & $\ldots$ \\
\hline 40.5 & 39 & $\begin{array}{ll}\ldots & 22\end{array}$ & .. 6 & . & 19 & 5 & ... 11 & ... 71 & $\ldots 51$ & ... 38 & $\ldots 2$ & $\cdots$ \\
\hline 0 & 40 & 2 & 5 & & 19 & 5 & .. 10 & 74 & 0 & ... 30 & ... 2 & \\
\hline & 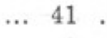 & 21 & 6 & & 1 & 5 & 12 & $1 x$ & & ... 42 & 4 & \\
\hline $43 \cdot 2$ & 40 & 政 & & & 19 & & 11 & 74 & ... 55 & ... 50 & .. 2 & \\
\hline$\$ 8.9$ & . 38 & $\ldots \quad 22$ & & & 17 & & ... 10 & $\ldots 74$ & ... 53 & $\ldots 44$ & & \\
\hline
\end{tabular}




\section{Locality: Norfolk. Coast.}

Females. Total Number, 91.

\begin{tabular}{|c|c|c|c|c|c|c|c|c|c|c|c|c|c|c|c|c|c|c|c|}
\hline $\begin{array}{l}\text { Length } \\
\mathrm{cm} .\end{array}$ & & $\begin{array}{l}\text { Ht. of } \\
\text { Body. }\end{array}$ & & $\begin{array}{l}\text { Length } \\
\text { of Head }\end{array}$ & & $\begin{array}{l}\text { Cau. } \\
\text { Ped. }\end{array}$ & & $\begin{array}{l}\text { Cau. } \\
\text { Fin. }\end{array}$ & & ee & & $\begin{array}{l}\text { Gill } \\
\text { Rakers }\end{array}$ & & $\begin{array}{l}\text { D. } \\
\text { Rays. }\end{array}$ & $\begin{array}{c}\text { A. } \\
\text { Rays. }\end{array}$ & & $\begin{array}{l}\text { illiated } \\
\text { Rays. }\end{array}$ & $\begin{array}{l}\text { Cil. } \\
\text { Body. }\end{array}$ & $\begin{array}{l}\text { Matu- } \\
\text { rity. }\end{array}$ \\
\hline $21 \cdot 5$ & $\ldots$ & 37 & $\ldots$ & 22 & $\ldots$ & 6 & ... & 19 & $\ldots$ & 5 & $\cdots$ & 9 & $\ldots$ & 70 & ... 54 . & $\ldots$ & - & - & .. i \\
\hline $22 \cdot 7$ & .. & 39 & $\ldots$ & - 23 & 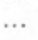 & 7 & $\ldots$ & 19 & $\cdots$ & 5 & $\ldots$ & 9 & ... & 71 & $\ldots \quad 55$ & . & - & & .. $\mathrm{i}$ \\
\hline $22 \cdot 7$ & $\ldots$ & 40 & $\ldots$ & 24 & $\ldots$ & 5 & $\ldots$ & 19 & $\ldots$ & 5 & $\ldots$ & 10 & $\ldots$ & 73 & .. 53 & $\ldots$ & - & $\ldots-$ & .. $\mathrm{i}$ \\
\hline $3 \cdot 0$ & .. & 40 & $\ldots$ & . 23 & 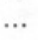 & 6 & ... & 18 & $\ldots$ & 5 & $\ldots$ & 10 & . & 73 & .. 56 & $\ldots$ & - & $\ldots-$ & $\ldots \mathrm{i}$ \\
\hline $23 \cdot 9$ &.. & 39 & $\ldots$ & 23 & $\ldots$ & 6 & $\ldots$ & 19 & $\ldots$ & 5 & $\ldots$ & 10 & $\ldots$ & 71 & $\ldots 56$ & $\ldots$ & - & $\ldots-$ & $\ldots \mathrm{i}$ \\
\hline $4 \cdot 7$ & . & 39 & . & 23 & 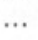 & 6 & $\ldots$ & 18 & $\ldots$ & 5 & $\ldots$ & 9 & $\ldots$ & 76 & $\ldots 56$ & $\ldots$ & - & $\ldots-$ & $\ldots \mathrm{i}$ \\
\hline $25 \cdot 6$ & .. & 37 & $\ldots$ & 22 & $\ldots$ & 7 & $\ldots$ & 17 & $\ldots$ & 5 & $\ldots$ & 9 & ... & 76 & $\ldots 56$ & $\ldots$ & - & $\ldots-$ & $\ldots \mathrm{i}$ \\
\hline $27 \cdot 0$ & $\ldots$ & 39 & $\ldots$ & . 22 & 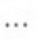 & 5 & $\ldots$ & 18 & $\ldots$ & 5 & $\ldots$ & 10 & $\ldots$ & 78 & $\ldots \quad 57$ & $\ldots$ & 25 & $\ldots-$ & $\ldots \mathrm{i}$ \\
\hline $27 \cdot 4$ & $\ldots$ & 40 & $\ldots$ & 24 & $\ldots$ & 5 & $\ldots$ & 19 & $\ldots$ & 6 & $\ldots$ & 10 & $\ldots$ & 69 & ... 52 & $\ldots$ & - & $\ldots-$ & $\ldots i$ \\
\hline $27 \cdot 5$ & $\ldots$ & 39 & $\ldots$ & 22 & . & 6 & $\ldots$ & 18 & $\ldots$ & 5 & $\ldots$ & 10 & $\ldots$ & 74 & $\ldots \quad 57$ & $\ldots$ & - & $\ldots-$ & $\ldots i$ \\
\hline $28 \cdot 5$ & $\ldots$ & 41 & $\ldots$ & 23 & $\ldots$ & 5 & $\ldots$ & 20 & $\ldots$ & 7 & $\ldots$ & 10 & $\ldots$ & 75 & ... 54 & $\ldots$ & - & $\ldots-$ & $\ldots \quad \mathrm{i}$ \\
\hline $8 \cdot 7$ & $\ldots$ & 38 & $\ldots$ & 22 & $\ldots$ & 7 & $\ldots$ & 18 & $\ldots$ & 5 & $\ldots$ & 10 & $\ldots$ & 74 & $\ldots 56$ & $\ldots$ & - & $\ldots-$ & $\ldots \quad \mathrm{i}$ \\
\hline $28 \cdot 8$ &.. & 39 & $\ldots$ & - 24 & $\ldots$ & 5 & $\ldots$ & 19 & $\ldots$ & 5 & $\ldots$ & 13 & ${ }^{\prime}{ }^{\prime}$ & 74 & ... 54 & $\ldots$ & - & ... -- & $\ldots \mathrm{i}$ \\
\hline $28 \cdot 9$ & $\ldots$ & 40 & $\ldots$ & 22 & $\ldots$ & 6 & $\ldots$ & 19 & $\ldots$ & 5 & $\ldots$ & 10 & $\ldots$ & 72 & .. 54 & $\ldots$ & - & $\ldots-$ & $\ldots$ i \\
\hline $29 \cdot 4$ & $\ldots$ & 37 & $\ldots$ & 22 & $\ldots$ & 6 & $\ldots$ & 19 & $\ldots$ & 5 & $\ldots$ & 11 & $\ldots$ & 71 & .. 53 & $\ldots$ & - & $\ldots-$ & $\ldots \mathrm{i}$ \\
\hline $30 \cdot 5$ & $\ldots$ & 40 & $\ldots$ & 23 & $\ldots$ & 6 & $\ldots$ & 19 & $\ldots$ & 4 & $\ldots$ & 11 & $\ldots$ & 75 & $\ldots \quad 55$ & $\ldots$ & - & $\ldots-$ & $\ldots i$ \\
\hline $31 \cdot 4$ & $\ldots$ & 39 & $\ldots$ & 23 & $\ldots$ & 6 & $\ldots$ & 18 & $\ldots$ & 5 & $\ldots$ & 10 & $\ldots$ & 72 & ... 54 & $\ldots$ & - & $\ldots-$ & $\ldots \mathrm{i}$ \\
\hline $31 \cdot 6$ & $\ldots$ & 38 & $\ldots$ & 23 & $\ldots$ & 6 & $\ldots$ & 17 & $\ldots$ & 5 & $\ldots$ & 11 & $\ldots$ & 72 & $\ldots \quad 54$ & $\ldots$ & - & $\ldots-$ & $\ldots \mathrm{i}$ \\
\hline 9 & $\ldots$ & 37 & $\ldots$ & 22 & $\ldots$ & 6 & $\ldots$ & 18 & $\ldots$ & 5 & $\ldots$ & 9 & $\ldots$ & 72 & $\ldots 53$ & $\ldots$ & - & $\ldots-$ & $\ldots \mathrm{i}$ \\
\hline $32 \cdot 0$ & $\ldots$ & 39 & $\ldots$ & 22 & $\ldots$ & 6 & $\ldots$ & 20 & $\ldots$ & 5 & $\ldots$ & 9 & $\ldots$ & 72 & ... 54 & $\ldots$ & - & $\ldots-$ & $\ldots \mathrm{i}$ \\
\hline 22 & $\ldots$ & 42 & $\ldots$ & . 22 & $\ldots$ & 6 & $\ldots$ & 19 & $\cdots$ & 5 & $\ldots$ & 10 & $\ldots$ & 73 & $\ldots \quad 54$ & $\ldots$ & - & $\ldots-$ & $\ldots \quad \mathrm{i}$ \\
\hline $33 \cdot 2$ & $\ldots$ & 42 & $\ldots$ & 23 & $\ldots$ & 5 & $\ldots$ & 19 &.. & 5 & $\ldots$ & 11 & $\ldots$ & 73 & ... 52 & $\ldots$ & - & $\ldots-$ & $\ldots \mathrm{i}$ \\
\hline $3:$ & . & 37 & $\ldots$ & 22 & $\ldots$ & 6 & $\ldots$ & 19 & $\ldots$ & 6 & $\ldots$ & 12 & $\ldots$ & 73 & $\ldots \quad 52$ & $\ldots$ & - & $\ldots-$ & $\ldots \quad \mathrm{i}$ \\
\hline $33 \cdot 8$ & $\ldots$ & 41 & $\ldots$ & 23 & $\ldots$ & 5 & $\ldots$ & 20 & $\ldots$ & 5 & $\ldots$ & 10 & $\ldots$ & 71 & ... 51 & $\ldots$ & - & $\ldots-$ & $\ldots \mathrm{i}$ \\
\hline 33.8 &. & 39 & $\ldots$ & 22 & $\ldots$ & 7 & $\ldots$ & 19 & $\ldots$ & 5 & $\ldots$ & 10 & $\ldots$ & 74 & $\ldots \quad 55$ & $\ldots$ & - & $\ldots-$ & $\ldots \quad \mathrm{i}$ \\
\hline $33 \cdot 9$ & $\ldots$ & 38 & $\ldots$ & 21 & $\cdots$ & 6 & $\ldots$ & 19 & $\ldots$ & 5 &.. & 11 & $\ldots$ & 71 & .. 53 & $\ldots$ & - & $\ldots-$ & $\ldots \mathrm{i}$ \\
\hline 1. & . & 38 & $\ldots$ & 23 & $\ldots$ & 5 & $\ldots$ & 19 & $\ldots$ & 5 & $\ldots$ & 10 & $\ldots$ & 73 & ... 53 & $\ldots$ & - & $\ldots-$ & $\ldots \quad \mathrm{i}$ \\
\hline $34 \cdot 7$ & $\ldots$ & 39 & $\ldots$ & 21 & $\ldots$ & 5 & $\ldots$ & 20 & $\ldots$ & 5 & $\ldots$ & 11 & $\ldots$ & 7 & $\ldots$ & $\ldots$ & - & $\ldots-$ & $\ldots \mathrm{i}$ \\
\hline 4.9 & ... & 40 & $\ldots$ & 21 & $\ldots$ & 6 & $\ldots$ & 19 & $\ldots$ & 5 & $\ldots$ & 10 & $\ldots$ & 74 & $\ldots \quad 55$ & $\ldots$ & - & $\ldots-$ & $\ldots$ i \\
\hline $34 \cdot 9$ & $\ldots$ & 41 & $\ldots$ & 23 & $\ldots$ & 6 & $\ldots$ & 19 & $\ldots$ & 5 & $\ldots$ & 10 & $\ldots$ & 7 & .. 52 & $\ldots$ & - & $\ldots-$ & $\ldots \mathrm{i}$ \\
\hline $35 \cdot 1$ & $\ldots$ & 39 & $\ldots$ & 22 & $\cdots$ & 6 & $\ldots$ & 19 & $\ldots$ & 5 & $\ldots$ & 11 & $\ldots$ & 72 & $\ldots \quad$ 52 & $\ldots$ & - & $\ldots-$ & $\ldots \quad \mathrm{i}$ \\
\hline $35 \cdot 1$ & $\ldots$ & 38 & $\ldots$ & 24 & $\ldots$ & 6 & ... & 1 & 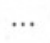 & 5 & & 9 & $\ldots$ & 73 & ... 53 & $\ldots$ & - & $\ldots-$ & $\ldots \mathrm{i}$ \\
\hline $35 \cdot 1$ & $\ldots$ & 37 & $\ldots$ & 23 & $\ldots$ & 6 & $\ldots$ & 18 & $\ldots$ & 6 & $\ldots$ & 8 & $\ldots$ & 71 & .. 53 & $\ldots$ & - & $\ldots-$ & $\ldots \mathrm{i}$ \\
\hline $35^{\circ} 4$ & $\ldots$ & 38 & $\ldots$ & 22 & $\ldots$ & 5 & 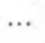 & 19 & $\ldots$ & 6 & $\cdots$ & 11 & $\ldots$ & 72 & ... 54 & $\ldots$ & - & $\ldots-$ & $\ldots \mathrm{m}$ \\
\hline $35 \cdot 5$ & $\ldots$ & 40 & $\ldots$ & 23 & $\ldots$ & 6 & $\ldots$ & 19 & $\ldots$ & 5 & $\ldots$ & 11 & $\ldots$ & 74 & .. 53 & $\ldots$ & - & $\ldots-$ & $\ldots i$ \\
\hline $35 \cdot 7$ & $\ldots$ & 39 & $\ldots$ & . 22 & $\ldots$ & 6 & $\ldots$ & 18 & $\ldots$ & 5 & $\ldots$ & 9 & $\ldots$ & 70 & $\ldots \quad 53$ & $\ldots$ & - & $\ldots-$ & $\ldots \mathrm{i}$ \\
\hline $36 \cdot 0$ & $\ldots$ & 40 & $\ldots$ & 23 & $\ldots$ & 6 & $\ldots$ & 20 & $\ldots$ & 5 & $\ldots$ & 10 & $\ldots$ & 72 & ... 52 & $\ldots$ & - & $\ldots-$ & $\ldots \mathrm{i}$ \\
\hline $36 \cdot 5$ & $\ldots$ & 38 & $\ldots$ & . 22 & $\ldots$ & 6 & $\ldots$ & 19 & $\ldots$ & 7 & .. & 9 & & 76 & .. 54 & $\ldots$ & - & $\ldots-$ & $\ldots \mathrm{i}$ \\
\hline $36 \cdot 6$ & $\ldots$ & 39 & $\ldots$ & 22 & $\ldots$ & 6 & $\ldots$ & 18 & $\ldots$ & 5 & $\ldots$ & 9 & $\ldots$ & 72 & .. 54 & $\ldots$ & - & ... - & $\ldots \mathrm{i}$ \\
\hline $36 \cdot 6$ & $\ldots$ & 37 & $\ldots$ & . 22 & $\cdots$ & 5 & $\ldots$ & 18 & $\ldots$ & 5 & $\ldots$ & 10 & $\ldots$ & 79 & .. 61 & $\ldots$ & - & $\ldots-$ & $\ldots \mathrm{i}$ \\
\hline $36 \cdot 7$ & $\ldots$ & 42 & $\ldots$ & . 23 & $\cdots$ & 5 & ..: & 18 & $\ldots$ & 5 & $\ldots$ & 8 & $\ldots$ & 67 & $\ldots \quad 52$ & $\ldots$ & - & $\ldots-$ & $\ldots \mathrm{i}$ \\
\hline $36 \cdot 7$ & $\cdots$ & 39 & $\ldots$ & 23 & $\cdots$ & 5 & $\cdots$ & 19 & $\cdots$ & 5 & $\cdots$ & 10 & $\ldots$ & 70 & .. 52 & $\cdots$ & - & $\ldots-$ & $\ldots-$ \\
\hline $37 \cdot 0$ & $\ldots$ & 37 & $\cdots$ & . 24 & $\cdots$ & 6 & $\cdots$ & 18 & $\ldots$ & 5 & $\cdots$ & 11 & $\cdots$ & 78 & $\ldots 57$ & $\cdots$ & - & $\ldots-$ & $\ldots \mathrm{i}$ \\
\hline $37 \cdot 9$ & $\cdots$ & 37 & $\ldots$ & . 23 & $\cdots$ & 6 & $\ldots$ & 18 & $\ldots$ & 5 & $\ldots$ & 11 & $\ldots$ & 70 & ... 52 & $\ldots$ & - & $\ldots-$ & $\ldots \mathrm{i}$ \\
\hline $37 \cdot 9$ & $\ldots$ & 36 & $\ldots$ & . 23 & $\ldots$ & 6 & $\ldots$ & 19 & $\cdots$ & 3 & " & 10 & $\cdots$ & 78 & $\ldots \quad 57$ & $\ldots$ & - & $\ldots-$ & $\ldots \mathrm{m}$ \\
\hline $38 \cdot 2$ & $\ldots$ & 37 & $\ldots$ & 23 & $\ldots$ & 6 & $\ldots$ & 18 & $\ldots$ & 5 & $\ldots$ & 11 & $\ldots$ & 72 & $\ldots \quad 55$ & $\ldots$ & - & $\ldots-$ & $\ldots \mathrm{m}$ \\
\hline $38 \cdot 5$ & & 39 & . & 22 & . & 5 & $\cdots$ & 19 & $\ldots$ & 5 & $\cdots$ & 12 & $\ldots$ & 72 & $\ldots \quad 53$ & $\cdots$ & - & $\ldots-$ & $\ldots \mathrm{m}$ \\
\hline $38 \cdot 6$ & & 40 & $\ldots$ & 22 & $\ldots$ & 5 & $\cdots$ & 20 & $\ldots$ & 4 & $\ldots$ & 11 & $\cdots$ & 73 & $\ldots \quad 53$ & $\ldots$ & - & $\ldots-$ & $\ldots \mathrm{m}$ \\
\hline $8 \cdot 8$ & & 38 & $\cdots$ & 22 & $\ldots$ & 6 & $\ldots$ & 18 & $\ldots$ & 4 & $\ldots$ & - & $\ldots$ & 70 & .. 51 & $\ldots$ & 20 & ... 0 & $\ldots \mathrm{i}$ \\
\hline
\end{tabular}




\section{Frmales-continued.}

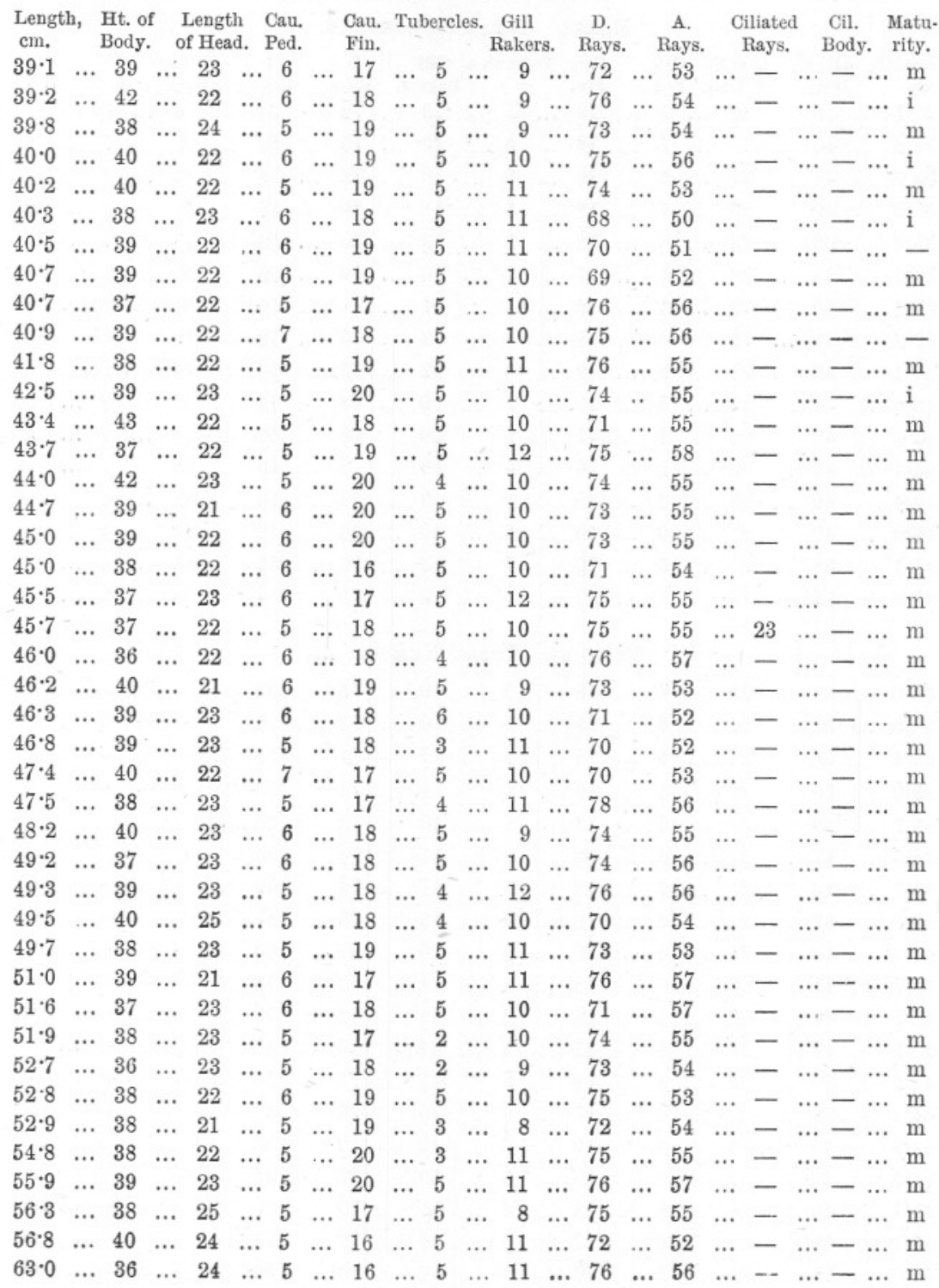


Locality: North-eastern end of Dogger Bank, 25 fathoms.

Males. Total Number, 16.

\begin{tabular}{|c|c|c|c|c|c|c|c|c|c|c|c|c|c|c|c|c|c|}
\hline $\begin{array}{l}\mathrm{cm} . \\
28 \cdot 7\end{array}$ & $\begin{array}{l}\text { ht. of } \\
\text { Body. } \\
\ldots \quad 38\end{array}$ & .. & $\begin{array}{l}\text { Lengt } \\
\text { of Hea } \\
22\end{array}$ & $\begin{array}{l}\text { I } \\
\ldots\end{array}$ & $\begin{array}{c}\text { Ped. } \\
5\end{array}$ & & $\begin{array}{c}\text { Fin. } \\
19\end{array}$ & & 5 & $\mathrm{R}$ & $\begin{array}{l}\text { Gill } \\
\text { Rakers. } \\
13 .\end{array}$ & $\begin{array}{l}\text { s. } \\
\ldots\end{array}$ & $\begin{array}{l}\text { D. } \\
\text { Rays. } \\
72\end{array}$ & $\begin{array}{c}\text { A. } \\
\text { Rays. } \\
\text {... } 54\end{array}$ & $\begin{array}{l}\text { Ciliated } \\
\text { Rays. } \\
\text {... } 0\end{array}$ & $\begin{array}{cc}\text { d } & \text { Cil. } \\
& \text { Body. } \\
\ldots & 0\end{array}$. & $\begin{array}{l}\text { Mati } \\
\text { y. rity } \\
\ldots .\end{array}$ \\
\hline $32 \cdot 8$ & 40 & $\cdots$ & 22 & 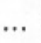 & 7 & .. & 18 & $\ldots$ & 5 & $\cdots$ & 10 & $\cdots$ & 70 & 53 & 0 & 0 & ; \\
\hline$\cdot 9$ & 41 & $\ldots$ & 21 & $\ldots$ & 6 & ... & 19 & .. & 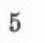 & .. & 10 & $\ldots$ & 73 & 54 & 33 & 2 & \\
\hline 3 & 0 & & 20 & & 7 & ... & 8 & . & & . & 11 & $\cdots$ & 70 & 52 & 44 & .. & . \\
\hline & 39 & .. & 23 & .. & 6 & $\ldots$ & 18 & .. & 2 & $\cdots$ & 10 & ... & 99 & 54 & 7 & & \\
\hline 2 & 38 &. & 22 & $\ldots$ & 6 & ... & 17 & . & 0 & $\cdots$ & 10 & .* & 70 & .. 55 & 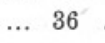 & 2 & $?$ \\
\hline & 10 &.. & 22 & ... & 5 & $\cdots$ & 19 & $\ldots$ & 3 & $\cdots$ & 11 & $\ldots$ & 74 & .. 56 & 34 & 2 & n \\
\hline 2. & & .. & 2 & $\ldots$ & 6 & $\ldots$ & 8 & $\ldots$ & 0 & $\cdots$ & 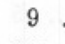 & $\cdots$ & 70 & .. 53 & ... 34 & $\cdots$ & $\cdots$ \\
\hline$\cdot 1$ & & .. & 2 & & & ... & & & & $\ldots$ & & $\cdots$ & 10 & $\ldots$ & $\ldots$ & $\ldots$ & $\cdots$ \\
\hline 6 & . 41 &.. & 21 & . & 6 & $\cdots$ & 19 & & 5 & $\ldots$ & 10 & $\cdots$ & & 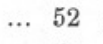 & $\ldots$ & $\ldots$ & $\cdots$ \\
\hline$\cdot 7$ & .. 42 &.. & 22 & . & 6 & $\ldots$ & 17 &. & 5 & $\ldots$ & 10 &. & 69 & 52 & 44 & 4 & \\
\hline$\cdot 4$ & . 42 & .. & 22 & . & 7 & $\ldots$ & 16 & $\ldots$ & 5 & ... & 10 & $\ldots$ & 72 & $\ldots \quad 55$ & .. 39 & $\ldots$ & $\cdots$ \\
\hline$\cdot 4$ & 40 & .. & 23 & $\ldots$ & 6 & $\ldots$ & 18 & $\ldots$ & 5 & ... & 9 &.. & 74 & .. 54 & .. 42 & .. 4 & $\cdots$ \\
\hline & 42 & .. & 1 & $\cdots$ & 6 & $\cdots$ & 8 & $\cdots$ & 5 & $\cdots$ & 10 & ... & 4 & 52 & 41 & 4 & $\ldots$ \\
\hline & 39 & $\cdots$ & 21 & $\cdots$ & 5 & $\cdots$ & 19 & $\cdots$ & 7 & $\ldots$ & 10 & $\cdots$ & 70 & 55 & 43 & 4 & m \\
\hline . & 35 & & 10 & & . & & 17 & & 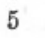 & & & & 10 & 54 & .. 48 & $\ldots 5$ & \\
\hline
\end{tabular}

Females. Total Number, 27.

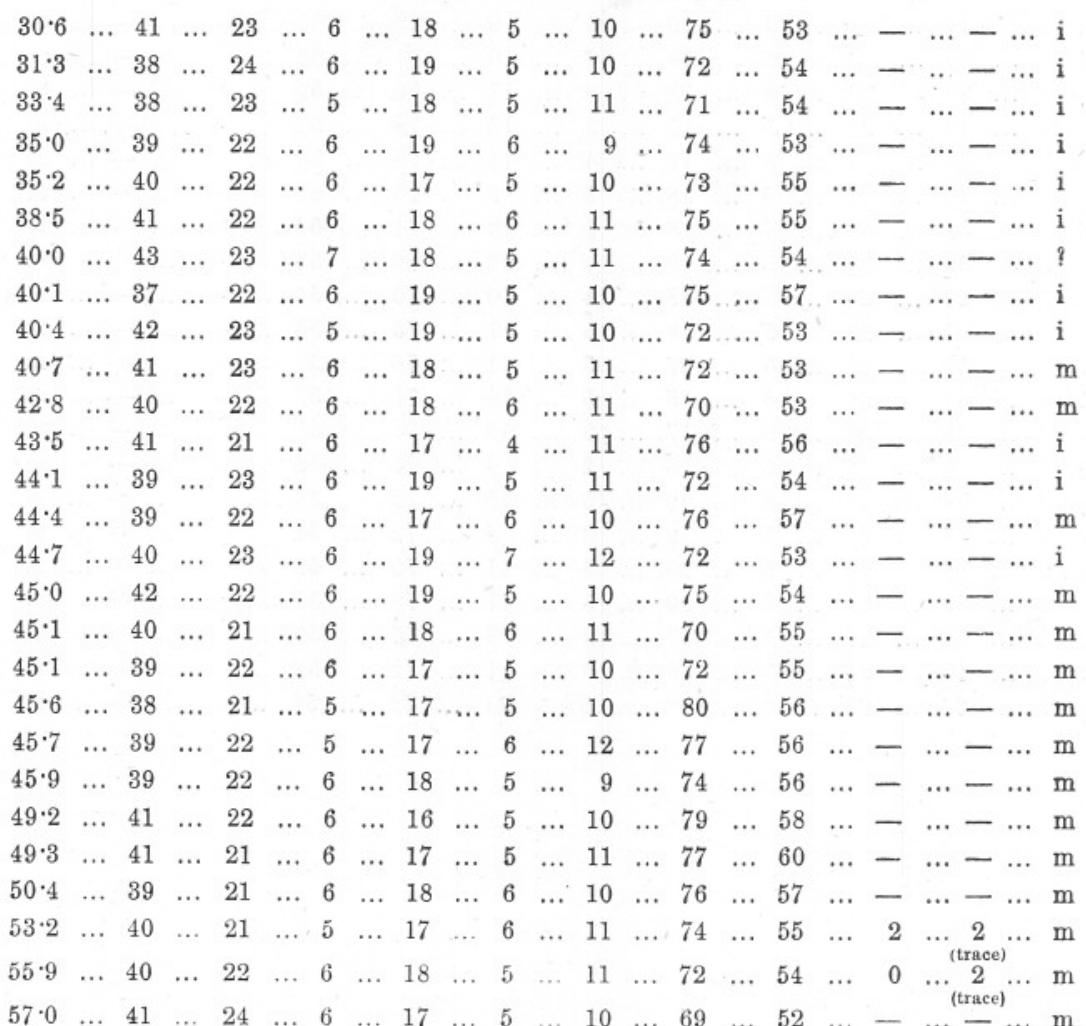


PECULIARITIES OF PLAICE FROM DIFFERENT FISHING GROUNDS. 353

\section{Locality: Off South Coast of Iceland.}

Specimen in spirit, collected by Mr. Holt.

\section{MaLe.}

Length, Ht. of Length Cau. Cau. Tubercles. Gill D. A. Ciliated Cil. Matucm. Body. of Head. Ped. Fin. Rakers. Rays. Rays. Rays. Body. rity. $\begin{array}{lllllllllllllllllllllll}60.6 & \ldots & 40 & \ldots & 21 & \ldots & 6 & \ldots & 19 & \ldots & 5 & \ldots & 9 & \ldots & 72 & \ldots & 54 & \ldots & 47 & \ldots & 5 & \ldots & -\end{array}$

\section{Locality: Fisher Bank, North Sea.}

Specimen in spirit, collected by Mr. Holt.

\section{Male.}

Length, Ht. of Length Cau. Cau. Tubercles, Gill D. A. Ciliated Cil. Matucm. Body. of Head. Ped. Fin. Rakers. Rays. Rays. Rays. Body. rity. $\begin{array}{llllllllllllllllllllllll}49 \cdot 1 & \ldots & 37 & \ldots & 23 & \ldots & 6 & \ldots & 17 & \ldots & 5 & \ldots & 11 & \ldots & 74 & \ldots & 55 & \ldots & 51 & \ldots & 5 & \ldots & -\end{array}$

\section{Locality: Baltic Sea.}

Specimens in spirit, sent to Mr. Holt from Hamburg, probably caught near Kiel.

MALES.

\begin{tabular}{|c|c|c|c|c|c|c|c|c|c|c|c|}
\hline $\begin{array}{l}\text { ength, } \\
\text { m. }\end{array}$ & $\begin{array}{l}\text { Ht. of } \\
\text { Body. }\end{array}$ & $\begin{array}{l}\text { Length } \\
\text { of Head. }\end{array}$ & $\begin{array}{l}\text { Cau. } \\
\text { Ped. }\end{array}$ & $\begin{array}{l}\text { Cau. } \\
\text { Fin. }\end{array}$ & Tubercles. & $\begin{array}{c}\text { Gill } \\
\text { Rakers }\end{array}$ & $\begin{array}{l}\text { D. } \\
\text { Rays. }\end{array}$ & $\begin{array}{c}\text { A. } \\
\text { Rays. }\end{array}$ & $\begin{array}{c}\text { Ciliated } \\
\text { Rays. }\end{array}$ & $\begin{array}{l}\text { Cil. } \\
\text { Body. }\end{array}$ & $\begin{array}{l}\text { Matu- } \\
\text { rity. }\end{array}$ \\
\hline $.5 \quad$. & ... 36 & f. 23 . & 6 & ... 20 & $\ldots 4$ (flat) $\ldots$ & 9 & 64 & 47 & .. 50 & $\begin{array}{llll}\ldots & 4 & \end{array}$ & - \\
\hline$\cdot 8$ & ... 40 & .. 23 & 7 & 19 & $\ldots 5$ & 9 & 70 & 54 & ... 50 & $\begin{array}{llll}\ldots & 5 & \ldots\end{array}$ & - \\
\hline & .. 37 & ... 23 & .. 6 & .. 21 & 5 & . 10 & 69 & 52 & ... 55 & $\begin{array}{llll}\ldots & 5 & \ldots\end{array}$ & - \\
\hline & 38 & .. 23 & 5 & .. 21 & $\ldots 5$ (flat) ... & 9 & .. 69 & 52 & 49 & 5 & - \\
\hline & 38 & .. 22 & 7 & .. 21 & ... 5 & . 11 & .. 65 & 48 & .. 29 & $\begin{array}{llll}\ldots & 5 & & \end{array}$ & - \\
\hline & 38 & 23 & 7 & .. 19 & .. 4 & 10 & 73 & 53 & ... 44 & $\begin{array}{llll}\ldots & 5 & \end{array}$ & - \\
\hline
\end{tabular}

\section{Females.}

\begin{tabular}{|c|c|c|c|c|c|c|c|c|c|c|c|c|c|c|c|c|c|c|}
\hline & 38 & & & & & & & & & & & & & & & & & $\cdots$ \\
\hline & 39 & & 5 &. & 6 & & 2 & & & & 9 & & & $\ldots$ & 1 & & - & - \\
\hline & 39 & $\ldots$ & & $\ldots$ & 6 & & ) & & 0 & . & 11 & & 01 & & 4 & . & - & $\cdots$ \\
\hline & & ... & & $\cdots$ & 6 & & ) & & 6 & & 9 & & v & & 5 & & - & $\ldots$ \\
\hline & 1 & & & . & & & & & & & 9 & & 75 & 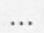 & 4 & $\ldots$ & - & \\
\hline
\end{tabular}




\section{PECULLIARIIIES OF PLAICE FROM DIFFERENT FISHING GROUNDS.}

SPECIMENS IN THE BRITISH MUSEUM COLLECTION.

Variety of Pleuronectes platessa.

Collected by U.S. Fishery steamer Albatross, at Herendeen Bay, Alaska.

Length, Ht. of Length Cau. Cau. Tubercles. Gill D. A. Ciliated Cil. Matu$\mathrm{cm}$. Body. of Head. Ped. Fin. Rakers. Rays. Rays. Rays. Body. rity. $\begin{array}{llllllllllllllllllllllllll}23 \cdot 3 & \ldots & 42 & \ldots & 24 & \ldots & 6 & \ldots & 18 & \ldots & 5 & \ldots & - & \ldots & 70 & \ldots & 51 & \ldots & 40 & \ldots & 0 & \ldots & \delta & \mathrm{i}\end{array}$

\section{Varieties of Pleuronectes glacialis.}

Collected by U.S. Fishery steamer in Nushagak River, Alaska.

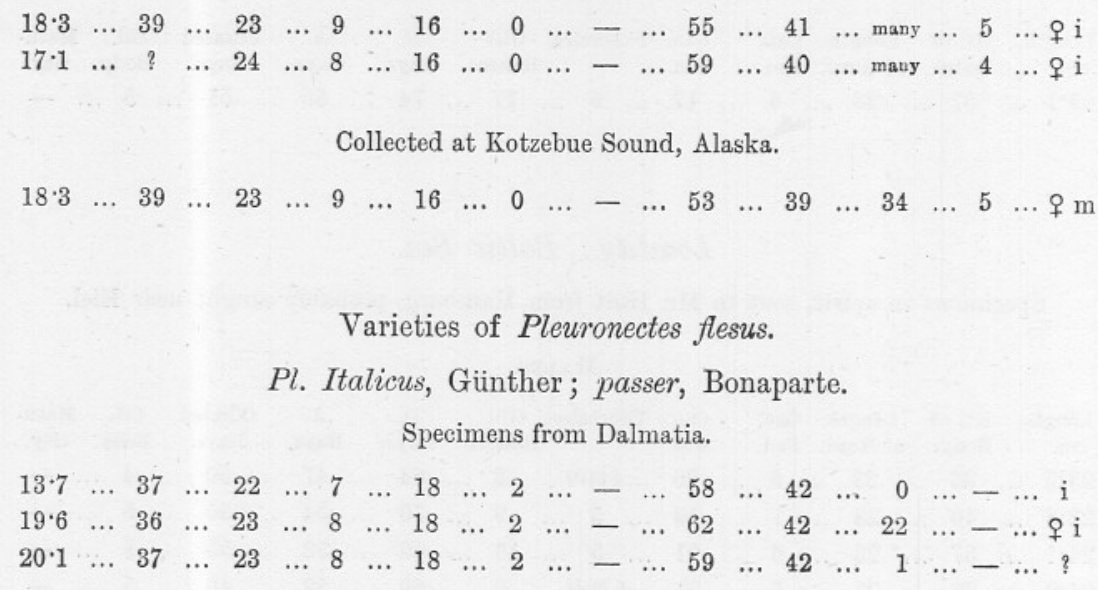

Varieties of Pleuronectes flesus.

Pl. Italicus, Günther; passer, Bonaparte.

Specimens from Dalmatia.

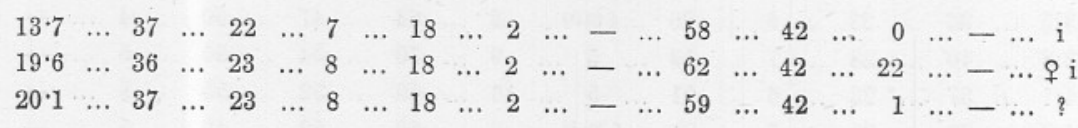

\section{Pl. 'luscus, Pallas.}

Specimens from the Bosphorus.

$\begin{array}{lllllllllllllllllllllll}28 \cdot 3 & \ldots & 42 & \ldots & 22 & \ldots & 7 & \ldots & 18 & \ldots & 2 & \ldots & - & \ldots & 60 & \ldots & 43 & \ldots & \text { few } & \ldots & - & \ldots & q \mathrm{~m} \\ 28.3 & \ldots & 37 & \ldots & 22 & \ldots & 8 & \ldots & 18 & \ldots & 2 & \ldots & - & \ldots & 56 & \ldots & 41 & \ldots & 28 & \ldots & - & \ldots & \delta \mathrm{m}\end{array}$

Specimens from the Black Sea.

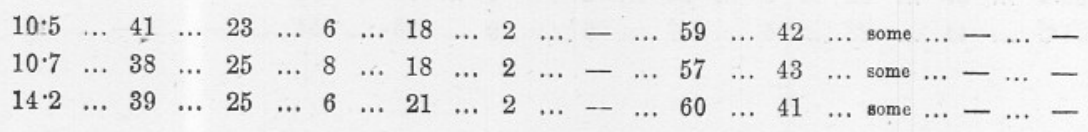

Specimens from Constantinople, labelled Platessa vulgaris.

$\begin{array}{lllllllllllllllllllllll}29 \cdot 1 & \ldots & 41 & \ldots & 23 & \ldots & 8 & \ldots & 19 & \ldots & 2 & \ldots & - & \ldots & 57 & \ldots & 42 & \ldots & \text { some } & \ldots & - & \ldots & \ldots\end{array}$ $\begin{array}{llllllllllllllllllllllll}34 \cdot 6 & \ldots & 43 & \ldots & 21 & \ldots & 8 & \ldots & 16 & \ldots & 2 & \ldots & - & \ldots & 59 & \ldots & 43 & \ldots & \text { some } & \ldots & - & \ldots\end{array}$ 
PECULIARITIES OF PLAICE FROM DIFFFERENT FISHING GROUNDS. 355

\section{B.-TABLES SHOWING THE NUMBER OF INDIVIDUALS IN WHICH EACH OBSERVED VARIATION OCCURRED.}

\begin{tabular}{|c|c|c|c|c|c|c|c|c|c|c|c|c|c|c|c|c|}
\hline \multirow{2}{*}{$\begin{array}{l}\text { Height of } \\
\text { Body in } \\
\text { hundredths } \\
\text { of Total } \\
\text { Length. }\end{array}$} & \multicolumn{2}{|c|}{ Plymouth. } & \multicolumn{3}{|c|}{ Brown Ridges. } & \multicolumn{2}{|c|}{ Norfolk Coast. } & \multicolumn{3}{|c|}{$\begin{array}{c}\text { N.E. of } \\
\text { Dogger Bank. } \\
\ldots \text { (16) (27) } \ldots\end{array}$} & \multicolumn{3}{|c|}{$\begin{array}{l}\text { Southern. } \\
\text { (67) (78) }\end{array}$} & \multicolumn{3}{|c|}{ Northern. } \\
\hline & б & $q$ & & $\delta$ & $q$ & $\sigma$ & $q$ & & б & $q$ & & $\sigma$ & $q$ & & 3 & ㅇ \\
\hline 35 . & $\ldots$ & - & $\ldots$ & 1 & - & $\ldots-$ & - & $\ldots$ & 1 & - & & 2 & - & $\ldots$ & 1 & - \\
\hline 36 & ... 1 & 1 & $\ldots$ & 7 & 6 & $\ldots$ & 4 & $\ldots$ & 0 & - . & ... & 8 & 7 & $\cdots$ & 4 & 4 \\
\hline 37 & $\ldots$ & 2 &.. & 8 & 7 & $\cdots$ & 16 & $\ldots$ & 0 & 1 & .. & 11 & 9 & $\ldots$ & 6 & 17 \\
\hline 38 & $\ldots$ & 10 & ... & 12 & 12 & $\ldots \quad 13$ & 1 & $\ldots$ & 2 & 3 & ... & 15 & 22 & $\ldots$ & 15 & 22 \\
\hline 39 & $\ldots$ & 3 & ... & 14 & 21 & ... 10 & 27 & $\ldots$ & 2 & 7 & ... & 18 & 24 & $\ldots$ & 12 & 34 \\
\hline 40 & $\ldots$ & 3 & ... & 8 & $\varepsilon$ & $\ldots \quad 11$ & 16 & $\cdots$ & 4 & 6 & $\cdots$ & 10 & 11 & $\cdots$ & 15 & 22 \\
\hline 41 & $\begin{array}{ll}\ldots & 1\end{array}$ & 2 & 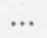 & 2 & 3 . & $\ldots$ & 3 & $\ldots$ & 3 & 7 & $\cdots$ & 3 & 5 & $\ldots$ & 5 & 10 \\
\hline 42 & ... - & - & $\cdots$ & - & - & $\ldots$ & 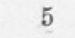 & $\ldots$ & 4 & 2 & .. & - & - & $\ldots$ & 6 & 7 \\
\hline 43 & $\ldots-$ & - & $\ldots$ & - & - & $\ldots$ & 1 & $\ldots$ & - & 1 & .. & - & - & $\ldots$ & 0 & 2 \\
\hline 44 & $\ldots-$ & - & ... & - & - & $\ldots$ & - & $\ldots$ & - & - & .. & - & - & $\ldots$ & 0 & - \\
\hline 45 & ... - & - & $\cdots$ & - & - & $\ldots$ & - & $\ldots$ & - &.- & $\ldots$ & - & - & $\ldots$ & 1 & - \\
\hline
\end{tabular}

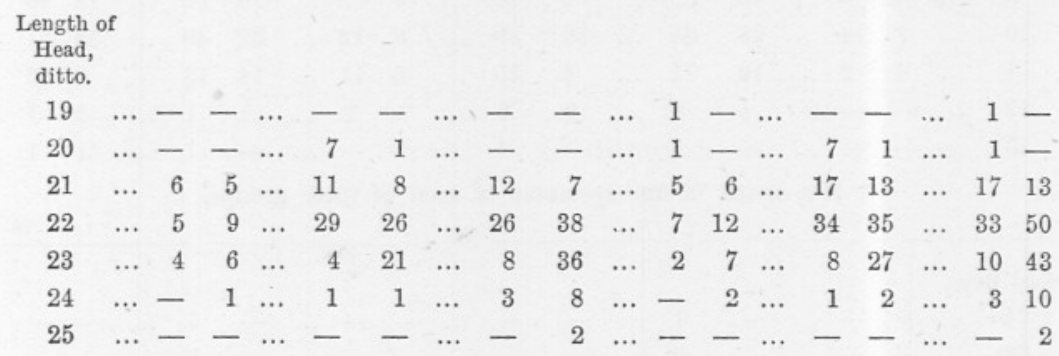

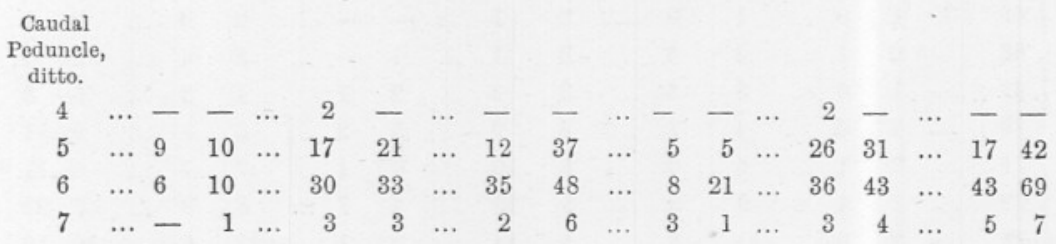




\begin{tabular}{|c|c|c|c|c|c|c|c|c|c|c|c|c|c|c|c|c|c|}
\hline \multirow{2}{*}{$\begin{array}{l}\text { Length of } \\
\text { Caudal Fin, } \\
\text { ditto. }\end{array}$} & \multicolumn{2}{|c|}{ Plymouth. } & \multicolumn{3}{|c|}{ Brown Ridges. } & \multicolumn{3}{|c|}{ Norfolk Coast. } & \multicolumn{4}{|c|}{$\begin{array}{c}\text { N.E. of } \\
\text { Dogger Bank. }\end{array}$} & \multicolumn{2}{|c|}{ Southern. } & \multicolumn{3}{|c|}{ Northern. } \\
\hline & $\sigma^{\sigma}$ & ㅇ & & 8 & 우 & & $\delta$ & 우 & & $\sigma$ & $q$ & & శ & $q$ & & 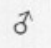 & 7 \\
\hline 16 & $\ldots-$ & - & $\ldots$ & 2 & - & $\ldots$ & - & 3 & $\ldots$ & 1 & 1 & & 2 & - & $\ldots$ & 1 & \\
\hline 17 & $\begin{array}{ll}\ldots & 1\end{array}$ & 3 & $\ldots$ & 11 & 16 & $\ldots$ & 7 & 11 & $\ldots$ & 3 & 9 & $\ldots$ & 12 & 19 & $\ldots$ & 10 & 20 \\
\hline 18 & $\ldots$ & 9 & .. & 26 & 28 & $\ldots$ & 14 & 30 & $\ldots$ & 6 & 10 & $\ldots$ & 31 & 37 & $\ldots$ & 20 & 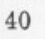 \\
\hline 19 & $\ldots$ & 5 & $\ldots$ & 9 & 10 & $\ldots$ & 20 & 35 & $\ldots$ & 6 & 7 & $\cdots$ & 16 & 15 & $\ldots$ & 26 & 42 \\
\hline 20 & $\ldots$ & 3 & . & 1 & 3 & $\ldots$ & 7 & 12 & $\ldots$ & - & - & $\ldots$ & 3 & 6 & $\cdots$ & 7 & 12 \\
\hline 21 & $\ldots-$ & 0 & .. & 2 & - & $\ldots$ & 1 & - & $\ldots$ & - & - & $\ldots$ & 2 & 0 & $\cdots$ & 1 & - \\
\hline 22 & $\ldots-$ & 0 & .. & 1 & - & $\ldots$ & - & - & $\ldots$ & - & - & $\ldots$ & 1 & 0 & $\ldots$ & - & - \\
\hline 23 & $\ldots-$ & 1 & .. & - & - & $\ldots$ & - & - & $\ldots$ & - & - & $\ldots$ & - & 1 & .. & - & \\
\hline
\end{tabular}

$$
\begin{aligned}
& \text { Number of } \\
& \text { Tubercles. } \\
& \begin{array}{rrrrrrrrrrrrrrrrrrr}
2 & \ldots & - & - & \ldots & - & - & \ldots & - & 2 & \ldots & - & - & \ldots & - & - & \ldots & - & 2 \\
3 & \ldots & 2 & - & \ldots & - & - & \ldots & 1 & 4 & \ldots & - & - & \ldots & 2 & - & \ldots & 1 & 4 \\
4 & \ldots & 2 & 1 & \ldots & - & - & \ldots & 7 & 8 & \ldots & - & 1 & \ldots & 2 & 1 & \ldots & 7 & 9 \\
5 & \ldots & 9 & 18 & \ldots & 42 & 45 & \ldots & 33 & 70 & \ldots & 13 & 17 & \ldots & 51 & 63 & \ldots & 46 & 87 \\
6 & \ldots & 2 & 1 & \ldots & 8 & 12 & \ldots & 7 & 5 & \ldots & 2 & 8 & \ldots & 10 & 13 & \ldots & 9 & 13 \\
7 & \ldots & - & 1 & \ldots & 2 & - & \ldots & 1 & 2 & \ldots & 1 & 1 & \ldots & 2 & 1 & \ldots & 2 & 3
\end{array}
\end{aligned}
$$

Gill Rakers.

\begin{tabular}{|c|c|c|c|c|c|c|c|c|c|c|c|c|c|c|c|c|c|c|}
\hline \multicolumn{19}{|c|}{ s. } \\
\hline 65 & $\ldots$ & - & - & $\ldots$ & - & . & $\ldots$ & - & - & $\ldots$ & - & - & $\ldots$ & - & 0 & $\ldots$ & - & - \\
\hline 6 & $\ldots$ & - & 1 & $\ldots$ & - & & $\ldots$ & - & - & $\ldots$ & - & - & $\ldots$ & - & 1 & $\ldots$ & - & - \\
\hline 67 & $\ldots$ & 1 & 0 & $\ldots$ & 1 & & $\ldots$ & 2 & 1 & $\ldots$ & - & - & $\ldots$ & 2 & 0 & $\ldots$ & 2 & 1 \\
\hline 68 & $\ldots$ & 0 & 1 & $\ldots$ & 3 & 3 & 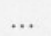 & 0 & 1 & $\ldots$ & 1 & - & $\ldots$ & 3 & 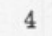 & 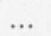 & 1 & 1 \\
\hline 69 & $\ldots$ & 1 & 0 & $\ldots$ & 3 & & $\cdots$ & 3 & 2 & & 2 & 1 & 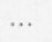 & 4 & 3 & & b & 3 \\
\hline 7 & $\ldots$ & 1 & 0 & $\ldots$ & 4 & & $\ldots$ & 4 & $y$ & 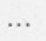 & 5 & 2 & .. & 5 & & . & 9 & 11 \\
\hline 7 & $\ldots$ & 2 & 1 & $\ldots$ & 5 & & 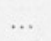 & 6 & 10 & $\cdots$ & 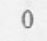 & 1 & .. & 7 & & $\ldots$ & 6 & 11 \\
\hline 72 & $\ldots$ & 3 & 4 & $\ldots$ & 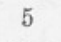 & & $\ldots$ & 5 & 15 & $\cdots$ & 2 & 7 & $\ldots$ & 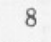 & & & 7 & 22 \\
\hline 73 & $\ldots$ & 2 & 0 & $\ldots$ & 11 & 5 & $\ldots$ & 0 & 14 & $\ldots$ & 2 & 1 & $\ldots$ & 13 & 5 & $\ldots$ & 10 & 15 \\
\hline 74 & $\ldots$ & 2 & 5 & $\ldots$ & 6 & 5 & .. & 10 & 12 & $\ldots$ & 3 & 4 & $\ldots$ & 8 & 10 & $\ldots$ & 13 & 16 \\
\hline 75 & $\ldots$ & 1 & 7 & $\ldots$ & 6 & 0 & 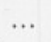 & 3 & 11 & $\ldots$ & 1 & 4 & .. & 7 & 13 & $\ldots$ & 4 & 15 \\
\hline 70 & $\ldots$ & 1 & 2 & ... & 5 & & & 6 & 11 & $\ldots$ & - & 3 & & 6 & & .. & 6 & 14 \\
\hline 77 & $\ldots$ & 1 & - & $\ldots$ & 1 & & $\ldots$ & 0 & 0 & $\ldots$ & - & 2 & 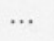 & 2 & 4 & $\cdots$ & 0 & 2 \\
\hline 78 & $\ldots$ & - & - & $\ldots$ & 2 & 1 & $\ldots$ & 1 & 4 & $\ldots$ & - & 0 & $\ldots$ & 2 & 1 & $\ldots$ & 1 & 4 \\
\hline 79 & $\ldots$ & - & - & $\ldots$ & - & 3 & & 1 & 1 & $\ldots$ & - & 1 & & - & 3 & $\ldots$ & 1 & 2 \\
\hline 80 & $\ldots$ & - & - & $\ldots$ & - & 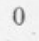 & ... & - & - & $\ldots$ & - & 1 & $\ldots$ & - & 0 & $\ldots$ & - & 1 \\
\hline 81 & $\ldots$ & - & - & $\ldots$ & - & 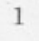 & $\ldots$ & - & - & $\ldots$ & - & - & $\ldots$ & - & 1 & $\ldots$ & - & - \\
\hline
\end{tabular}

$\begin{array}{rrrrrrrrrrrrrrrrrrrr}8 & \ldots & - & - & \ldots & - & - & \ldots & 1 & 4 & \ldots & - & - & \ldots & - & - & \ldots & 1 & 4 \\ 9 & \ldots & 4 & 4 & \ldots & 16 & 8 & \ldots & 9 & 16 & \ldots & 3 & 2 & \ldots & 20 & 12 & \ldots & 12 & 18 \\ 10 & \ldots & 7 & 14 & \ldots & 25 & 35 & \ldots & 30 & 39 & \ldots & 9 & 12 & \ldots & 32 & 49 & \ldots & 39 & 51 \\ 11 & \ldots & 4 & 2 & \ldots & 10 & 11 & \ldots & 6 & 25 & \ldots & 2 & 11 & \ldots & 14 & 13 & \ldots & 8 & 36 \\ 12 & \ldots & - & - & \ldots & 1 & 1 & \ldots & 2 & 5 & \ldots & 1 & 2 & \ldots & 1 & 1 & \ldots & 3 & 7 \\ 13 & \ldots & - & - & \ldots & - & 1 & \ldots & - & 1 & \ldots & 1 & - & \ldots & - & 1 & \ldots & 1 & 1\end{array}$

* Not noted in one specimen of each of these groups. 
PECULIARITIES OF PLAICE FROM DIFFERENT FISHING GROUNDS. 357

\begin{tabular}{|c|c|c|c|c|c|c|c|c|c|c|c|c|c|c|c|c|c|}
\hline \multirow[t]{2}{*}{ nal Rays. } & & \multicolumn{2}{|c|}{ Plymouth. } & \multicolumn{2}{|c|}{ Brown Ridges. } & \multicolumn{3}{|c|}{ Norfolk Coast. } & \multicolumn{4}{|c|}{$\begin{array}{c}\text { N.E. of } \\
\text { Dogger Bank. }\end{array}$} & \multicolumn{2}{|c|}{ Southern. } & \multicolumn{3}{|c|}{ Northern } \\
\hline & & $\delta$ & q & శ & q & & $\sigma$ & q & & 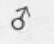 & ㅇ & & б & $q$ & & శ & $f$ \\
\hline 48 & $\ldots$ & - & $=$ & .. - & 1 & & - & 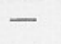 & 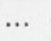 & - & - & 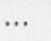 & 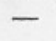 & & & - & - \\
\hline 49 & $\ldots$ & - & - & $\ldots \quad-$ & 0 & & 1 & - & ... & - & - & 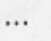 & - & 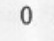 & & 1 & - \\
\hline 50 & $\cdots$ & - & - & .. & 3 & & 0 & 1 & $\cdots$ & - & - & & 0 & & & & \\
\hline & $\cdots$ & - & 2 & 5 & & & & & & - & - & & & & & & \\
\hline 52 & $\ldots$ & 3 & 1 & . & 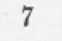 & $\cdots$ & 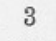 & 13 & ... & 4 & 1 & $\ldots$ & 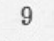 & 0 & $\cdots$ & 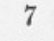 & 14 \\
\hline 53 & $\cdots$ & 4 & 2 & ... 10 & 3 & $\cdots$ & 10 & 17 & $\ldots$ & 2 & 6 & ... & 14 & & $\cdots$ & 12 & 23 \\
\hline 54 & $\cdots$ & 2 & 1 & $\cdots$ & 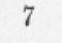 & $\cdots$ & 10 & & $\cdots$ & 6 & 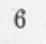 & .. & 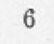 & & $\ldots$ & 16 & . \\
\hline & $\cdots$ & 2 & 6 & 1 & & & & & & & & & 6 & & & & 23 \\
\hline & $\cdots$ & 3 & 7 & .. & & & & 12 & & 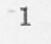 & 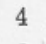 & .. & 9 & 1. & & & 16 \\
\hline 5 & $\cdots$ & 0 & 2 & .. & 7 & $\cdot \cdot$ & 7 & 8 & $\cdots$ & - & 3 & .. & 2 & & & 7 & 11 \\
\hline 58 & $\cdots$ & 1 & - & 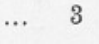 & 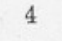 & .. & 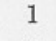 & 1 & $\cdots$ & - & 1 & ... & 4 & 4 & .. & 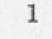 & \\
\hline 5 & $\ldots$ & - & - & ... - & 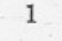 & 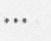 & 1 & & $\ldots$ & - & 0 & $\cdots$ & - & 1 & .. & 1 & \\
\hline 00 & $\cdots$ & - & - & $\ldots-$ & - & . & - & 0 & $\cdots$ & - & 1 & $\cdots$ & - & - & . & - & \\
\hline 61 & 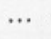 & - & - & $\ldots \quad-$ & - & .. & - & 1 & $\cdots$ & - & - & $\ldots$ & - & - & $\ldots$ & - & \\
\hline
\end{tabular}

Ciliation. Plymouth. Brown Ridges. Norfolk Coast. N.E. of Southern. Northern.

$$
\text { 急 Dogger Bank, }
$$

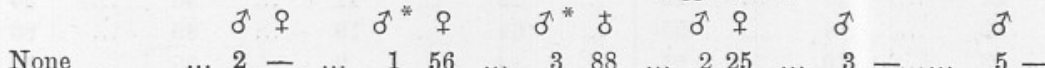

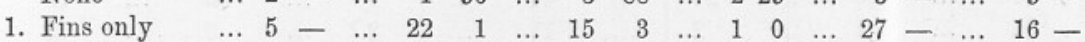

2. Also head $\ldots 6-\ldots 23-\ldots 18-\ldots .52 \ldots 29-\ldots 23-$

3. Also operculum.. $1-\ldots \quad 4-\ldots .3-\ldots .1-\ldots 5-\ldots 4-$

4. Also interspinous

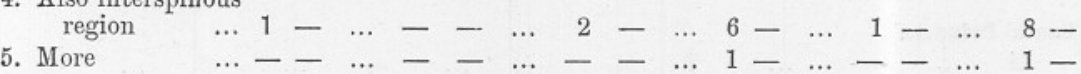

* Specimens under $26 \mathrm{~cm}$. in length not included. 
358 PECULIARITIES OF PLAICE FRON DIF̈FERENT FISHING GROUNDS̀.

TABLE SHOWING THE FREQUENCY OF EACH VARIATION WITHOUT SEPARATION OF SEXES.

\begin{tabular}{cccccccccccccc}
$\begin{array}{c}\text { Height of } \\
\text { Body. }\end{array}$ & \multicolumn{3}{c}{ Plymouth. } & \multicolumn{1}{c}{ Brown Ridges. Norfolk Coast. $\begin{array}{c}\text { N.E. of } \\
\text { Dogger Bank. }\end{array}$} & \multicolumn{3}{c}{ Southern. } & Northern. \\
& & \multicolumn{1}{c}{$(36)$} & $\ldots$ & $(109)$ & $\ldots$ & $(140)$ & $\ldots$ & $(43)$ & $\ldots$ & $(145)$ & $\ldots$ & $(183)$ \\
35 & $\ldots$ & 1 & $\ldots$ & 1 & $\ldots$ & - & $\ldots$ & 1 & $\ldots$ & 2 & $\ldots$ & 1 \\
36 & $\ldots$ & 2 & $\ldots$ & 13 & $\ldots$ & 8 & $\ldots$ & 0 & $\ldots$ & 15 & $\ldots$ & 8 \\
37 & $\ldots$ & 5 & $\ldots$ & 15 & $\ldots$ & 22 & $\ldots$ & 1 & $\ldots$ & 20 & $\ldots$ & 23 \\
38 & $\ldots$ & 13 & $\ldots$ & 24 & $\ldots$ & 32 & $\ldots$ & 5 & $\ldots$ & 37 & $\ldots$ & 37 \\
39 & $\ldots$ & 7 & $\ldots$ & 35 & $\ldots$ & 37 & $\ldots$ & 9 & $\ldots$ & 42 & $\ldots$ & 46 \\
40 & $\ldots$ & 5 & $\ldots$ & 16 & $\ldots$ & 27 & $\ldots$ & 10 & $\ldots$ & 21 & $\ldots$ & 37 \\
41 & $\ldots$ & 3 & $\ldots$ & 5 & $\ldots$ & 5 & $\ldots$ & 10 & $\ldots$ & 8 & $\ldots$ & 15 \\
42 & $\ldots$ & - & $\ldots$ & - & $\ldots$ & 7 & $\ldots$ & 6 & $\ldots$ & - & $\ldots$ & 13 \\
43 & $\ldots$ & - & $\ldots$ & - & $\ldots$ & 1 & $\ldots$ & 1 & $\ldots$ & - & $\ldots$ & 2 \\
44 & $\ldots$ & - & $\ldots$ & - & $\ldots$ & 0 & $\ldots$ & - & $\ldots$ & - & $\ldots$ & 0 \\
45 & $\ldots$ & - & $\ldots$ & - & $\ldots$ & 1 & $\ldots$ & - & $\ldots$ & - & $\ldots$ & 1 \\
& & & & & & & & & & & & \\
\hline
\end{tabular}

\begin{tabular}{|c|c|c|c|c|c|c|c|c|c|c|c|c|}
\hline \multicolumn{12}{|c|}{ Length of Head. } & 1 \\
\hline 20 & $\ldots$ & - & $\ldots$ & 8 & $\ldots$ & - & $\ldots$ & 1 & $\ldots$ & 8 & $\ldots$ & 1 \\
\hline 21 & $\ldots$ & 11 & $\ldots$ & 19 & $\ldots$ & 19 & $\ldots$ & 11 & $\ldots$ & 30 & $\ldots$ & 30 \\
\hline 22 & $\ldots$ & 14 & $\ldots$ & 55 & $\ldots$ & 64 & $\ldots$ & 19 & $\ldots$ & 69 & $\ldots$ & 83 \\
\hline 23 & $\ldots$ & 10 & $\ldots$ & 25 & $\ldots$ & 44 & $\ldots$ & 9 & $\ldots$ & 35 & $\ldots$ & 53 \\
\hline 24 & $\ldots$ & 1 & $\ldots$ & 2 & $\ldots$ & 11 & $\ldots$ & 2 & $\ldots$ & 3 & $\ldots$ & 13 \\
\hline 25 & $\ldots$ & - & $\ldots$ & - & $\ldots$ & 2 & $\ldots$ & - & $\ldots$ & - & $\ldots$ & 2 \\
\hline
\end{tabular}

$\begin{array}{ccrlrlrlrrrrrr}\text { Caudal Peduncle. } & & & & & & & & & & & \\ 4 & \ldots & - & \ldots & 2 & \ldots & - & \ldots & - & \ldots & 2 & \ldots & - \\ 5 & \ldots & 19 & \ldots & 38 & \ldots & 49 & \ldots & 10 & \ldots & 57 & \ldots & 59 \\ 6 & \ldots & 16 & \ldots & 63 & \ldots & 83 & \ldots & 29 & \ldots & 79 & \ldots & 112 \\ 7 & \ldots & 1 & \ldots & 6 & \ldots & 8 & \ldots & 4 & \ldots & 7 & \ldots & 12\end{array}$

$\begin{array}{crrrrrrrrrrrr}\text { Caudal Fin. } & & & & & & & & & & & & \\ 16 & \ldots & - & \ldots & 2 & \ldots & 3 & \ldots & 2 & \ldots & 2 & \ldots & 5 \\ 17 & \ldots & 4 & \ldots & 27 & \ldots & 18 & \ldots & 12 & \ldots & 31 & \ldots & 30 \\ 18 & \ldots & 14 & \ldots & 54 & \ldots & 44 & \ldots & 16 & \ldots & 68 & \ldots & 60 \\ 19 & \ldots & 12 & \ldots & 19 & \ldots & 55 & \ldots & 13 & \ldots & 31 & \ldots & 68 \\ 20 & \ldots & 5 & \ldots & 4 & \ldots & 19 & \ldots & - & \ldots & 9 & \ldots & 19 \\ 21 & \ldots & 0 & \ldots & 2 & \ldots & 1 & \ldots & - & \ldots & 2 & \ldots & 1 \\ 22 & \ldots & 0 & \ldots & 1 & \ldots & - & \ldots & - & \ldots & 1 & \ldots & - \\ 23 & \ldots & 1 & \ldots & - & \ldots & - & \ldots & - & \ldots & 1 & \ldots & -\end{array}$

Number of Tubercles.

$$
\begin{array}{rrrlrlrlrlrrr}
2 & \ldots & - & \ldots & - & \ldots & 2 & \ldots & - & \ldots & - & \ldots & 2 \\
3 & \ldots & 2 & \ldots & - & \ldots & 5 & \ldots & - & \ldots & 2 & \ldots & 5 \\
4 & \ldots & 3 & \ldots & - & \ldots & 15 & \ldots & 1 & \ldots & 3 & \ldots & 16 \\
5 & \ldots & 27 & \ldots & 87 & \ldots & 103 & \ldots & 30 & \ldots & 114 & \ldots & 133 \\
6 & \ldots & 3 & \ldots & 20 & \ldots & 12 & \ldots & 10 & \ldots & 23 & \ldots & 22 \\
7 & \ldots & 1 & \ldots & 2 & \ldots & 3 & \ldots & 2 & \ldots & 3 & \ldots & 5
\end{array}
$$


PECULIARITIES OF PLAICE FROM DIFFERENT FISHING GROUNDS. 359

Gill Rakers. Plymouth. Brown Ridges. Norfolk Coast. $\begin{gathered}\text { N.E. of } \\ \text { Dogger Bank. }\end{gathered}$ Southern. Northern.

$\begin{array}{rrrrrrrrrrrrr}8 & \ldots & - & \ldots & - & \ldots & 5 & \ldots & - & \ldots & - & \ldots & 5 \\ 9 & \ldots & 8 & \ldots & 24 & \ldots & 25 & \ldots & 5 & \ldots & 32 & \ldots & 30 \\ 10 & \ldots & 21 & \ldots & 60 & \ldots & 69 & \ldots & 21 & \ldots & 81 & \ldots & 90 \\ 11 & \ldots & 6 & \ldots & 21 & \ldots & 31 & \ldots & 13 & \ldots & 27 & \ldots & 44 \\ 12 & \ldots & - & \ldots & 2 & \ldots & 7 & \ldots & 3 & \ldots & 2 & \ldots & 10 \\ 13 & \ldots & - & \ldots & 1 & \ldots & 1 & \ldots & 1 & \ldots & 1 & \ldots & 2\end{array}$

\begin{tabular}{|c|c|c|c|c|c|c|c|c|c|c|c|c|}
\hline Dorsal I & & & & & & & & & & & & \\
\hline 64 & $\ldots$ & - & $\ldots$ & 1 & $\ldots$ & - & $\ldots$ & - & $\ldots$ & 1 & $\ldots$ & - \\
\hline 65 & $\ldots$ & - & $\ldots$ & 0 & $\ldots$ & - & $\ldots$ & - & $\ldots$ & 0 & $\ldots$ & - \\
\hline 66 & $\ldots$ & 1 & $\ldots$ & 0 & $\ldots$ & - & $\cdots$ & - & $\ldots$ & 1 & $\ldots$ & - \\
\hline 67 & $\ldots$ & 1 & $\ldots$ & 1 & $\ldots$ & 3 & $\ldots$ & - & $\ldots$ & 2 & $\ldots$ & 3 \\
\hline 68 & $\ldots$ & 1 & $\ldots$ & 6 & $\ldots$ & 1 & $\ldots$ & 1 & $\ldots$ & 7 & $\ldots$ & 2 \\
\hline 69 & $\ldots$ & 1 & $\ldots$ & 6 & $\ldots$ & 5 & $\ldots$ & 3 & $\ldots$ & 7 & $\ldots$ & 8 \\
\hline 70 & $\ldots$ & 1 & $\ldots$ & 11 & $\ldots$ & 13 & $\ldots$ & 7 & $\ldots$ & 12 & $\ldots$ & 20 \\
\hline 71 & $\ldots$ & 3 & $\ldots$ & 11 & $\ldots$ & 16 & $\ldots$ & 1 & $\ldots$ & 14 & $\ldots$ & 17 \\
\hline 72 & $\ldots$ & 7 & $\ldots$ & 10 & $\ldots$ & 20 & $\ldots$ & 9 & $\ldots$ & 17 & $\cdots$ & 29 \\
\hline 73 & $\ldots$ & 2 & $\ldots$ & 16 & $\ldots$ & 22 & $\ldots$ & 3 & $\ldots$ & 18 & $\ldots$ & 25 \\
\hline 74 & $\ldots$ & 7 & $\ldots$ & 11 & $\ldots$ & 22 & $\ldots$ & 7 & $\ldots$ & 18 & $\ldots$ & 29 \\
\hline 75 & $\ldots$ & 8 & $\ldots$ & 12 & $\ldots$ & 14 & $\ldots$ & 5 & $\ldots$ & 20 & $\ldots$ & 19 \\
\hline 76 & $\ldots$ & 3 & $\ldots$ & 12 & $\ldots$ & 17 & $\ldots$ & 3 & $\ldots$ & 15 & $\ldots$ & 20 \\
\hline 77 & $\ldots$ & 1 & $\ldots$ & 5 & $\ldots$ & 0 & $\ldots$ & 2 & $\ldots$ & 6 & $\ldots$ & 2 \\
\hline 78 & $\ldots$ & - & $\ldots$ & 3 & $\ldots$ & 5 & $\ldots$ & 0 & $\ldots$ & 3 & $\ldots$ & 5 \\
\hline 79 & $\ldots$ & - & $\ldots$ & 3. & $\ldots$ & 2 & $\ldots$ & 1 & $\ldots$ & 3 & $\ldots$ & 3 \\
\hline 80 & $\ldots$ & - & $\ldots$ & 0 & $\ldots$ & - & $\ldots$ & 1 & $\ldots$ & 0 & $\ldots$ & 1 \\
\hline 81 & $\ldots$ & - & $\ldots$ & 1 & $\ldots$ & - & $\ldots$ & - & $\ldots$ & 1 & $\ldots$ & - \\
\hline
\end{tabular}

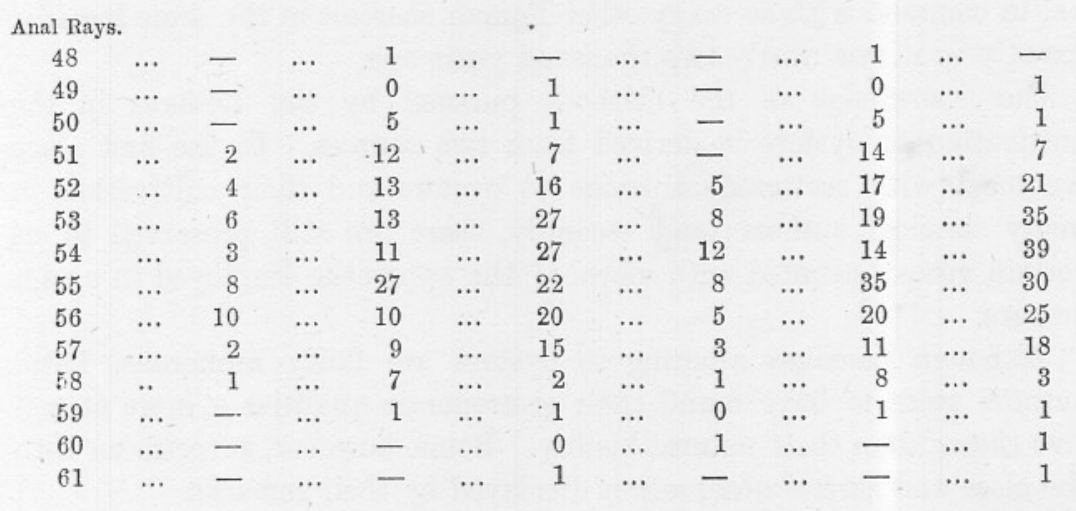

